\title{
Photovoltaic Solar Energy: Is It Applicable in Brazil? - A Review Applied to Brazilian Case
}

\author{
Fotovoltaična sončna energija: ali je uporabna v Brazliji? - \\ Pregled, uporaben za primer Brazilije
}

\author{
Wilmer Emilio García Moreno ${ }^{1, *}$, Andressa Ullmann Duarte', Litiéle dos Santos', Rogério Vescia Lourega ${ }^{1,2}$ \\ ${ }^{1}$ Graduation Program in Materials Engineering and Technology, Pontifical Catholic University of Rio Grande do Sul (PGETEMA/ \\ PUCRS), Brazil \\ 2 Pontifical Catholic University of Rio Grande do Sul (PUCRS), Brazil \\ *wilgm93@gmail.com
}

\begin{abstract}
The photovoltaic technologies have been developed year by year in different countries; however, there are some countries where this kind of energy is being born, such as the Brazilian case. In this paper, some important parameters are analysed and applied to different solar cell materials, identifying that if the fossil fuels were substituted by solar cells, it would reduce the $\mathrm{CO}_{2}$ emissions by $93.2 \%$. In addition, it is shown that the efficiency of solar cells is not as farther as it could be thought from coal thermoelectrical plants in Brazil and the cost of energy using solar cells could be as good as these thermoelectrical plants. Finally, the potentiality of Brazilian territory to implant this technology is presented, identifying that with the use of $0.2 \%$ of the territory, the energy demand could be supplied.
\end{abstract}

Key words: Solar cells, $\mathrm{CO}_{2}$ Emissions, Fossil fuels, Brazil, Thermoelectrical plants

\section{Povzetek}

Fotovoltaične tehnologije se iz leta v leto razvijajo v različnih državah. Obstajajo nekatere države, kot na primer Brazilija, kjer ta vrsta energije igra pomembno vlogo. Zaradi tega smo v članku analizirali nekatere pomembne parametre, ki se nanašajo na različne material sončnih celic. Ugotovili smo, da bi se v primeru zamenjave fosilnih goriv s sončnimi celicami izpusti $\mathrm{CO}_{2}$ lahko zmanjšali v najboljšem primeru za 93.2\%. Prav tako smo pokazali, da učinkovitost sončnih celic in cena z njimi pridobljene energije ne zaostaja za termoelektrarnami v Braziliji. Na koncu je predstavljen potencial ozemlja Brazilije, kjer bi lahko z uporabo $0.2 \%$ ozemlja pokrili energetske potrebe.

Ključne besede: sončne celice, emisije $\mathrm{CO}_{2}$, fosilna goriva, Brazilija, termoelektrarne 


\section{Introduction}

Both economic and population growth have an effect on energy demand, having as principal consequence an accumulative increase in the use of fossil fuels, a way to supply this demand, increasing the average greenhouse gases concentration, being the $\mathrm{CO}_{2}$ the principal gas among them [1]; therefore, the biggest challenge is to reduce the $\mathrm{CO}_{2}$ emissions to the atmosphere by means of using diverse green energy sources, such as natural gas, ethanol, nuclear, wind and solar energy [2]. In this order of ideas, the concern in these alternative energies has been bigger in conformity of the growing global warming and air pollution [3].

Some countries have implemented the use of renewable energy in order to solve the environmental problems, solar photovoltaic systems being one of them [4] and is also placed as one of the most promising energies because of its potential to reduce greenhouse gases (GHG) emissions [5] and how not considering as it, when along its operational time it does not emit $\mathrm{CO}_{2}$ ? [6] [7]. Also, an important parameter has been studied and it is its pricing by $\mathrm{Wp}$ (Watts Peak), being reported 1.60 US\$/Wp in 2011, 0.34 US $\$ / W p$ in 2017 and reduced to 0.244 US $\$ / W p$ in January 2019 [8].

On the other hand, placing the focus on Brazil, its grid is composed by $67.9 \%$ of hydroelectrical sources; however, the photovoltaic energy occupies a low $0.7 \%$ [9]. Also even when the hydroelectrical source is considered clean, its application is restricted due to environmental impact, such as flooding in large areas, methane emissions from anaerobic degradation of organic material, dependence on local hydrological stability [10]. In addition, because of the climate change, more frequent, intense and prolonged droughts in Brazil are expected, which would affect dramatically the hydroelectrical source [11].

Hence, due to all the above mentioned environmental impact, this work tries to show a review focused on some specific parameters such as the GHG emission, energy payback time (EPBT), energy return on energy invested (ERoEI), efficiency, cost and irradiance potentiality and focused on different materials to know how green this energy (no matter about the solar cell material) can be and how it can be applied in Brazil, trying to illustrate how the country could be helped, due to its enormous capability [12] [13].

\section{Cell Technologies}

In brief, solar cells transform the solar power to electrical power. This photovoltaic cell is created by a semiconductor material which is exposed to the photons emerging from sunlight. This semiconductor has an absorption capacity, depending on its specific band gap energy that will absorb photons with the same energy (the band gap energy) and, if the energy is higher, these photons will release the surplus energy in heat form and, in that way, retaining the specific band gap energy of the material [14]. Having in consideration the different kinds of materials, the global share is illustrated in Figure 1.

Monocrystalline photovoltaic cells are made using a single and continuous crystal of silicon, having almost no impurities, obtaining a blue solid colour [15], sharing around $30 \%$ of

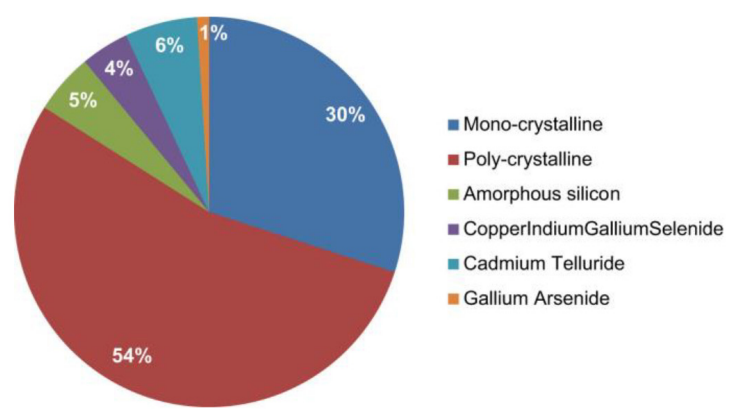

Figure 1: Global market share of photovoltaic cells [14].

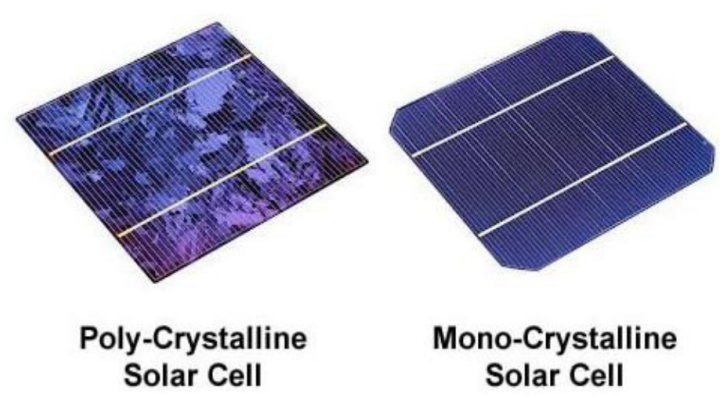

Figure 2: Silicon solar cells [19]. 


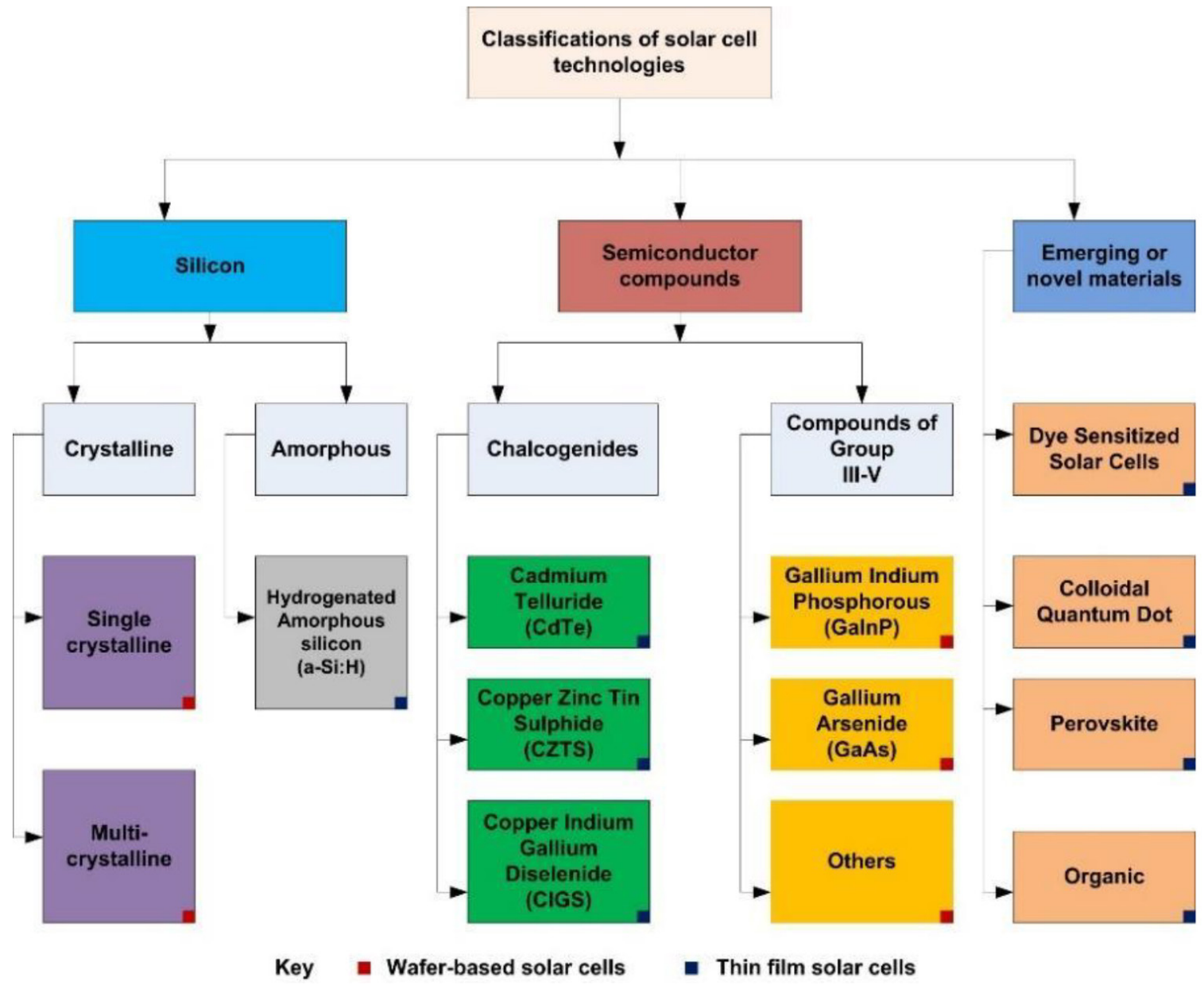

Figure 3: Solar cell technologies classification [26].

the market (Figure 1). The manufacturing of these cells is more expensive due to processing of high purity crystal and also guaranteeing a higher efficiency compared with polycrystalline cells [16] [17]. On the other hand, polycrystalline photovoltaic cells occupied most of the market share (more than 50\%) (Figure 2). They are produced using several different monocrystalline silicon grains which are melted and consequently solidified slowly by cooling down [18].

Another kind of photovoltaic cells are thin films which are known as second generation of photovoltaic cells, having a range of thickness varying between $10 \mathrm{~nm}$ to $10 \mu \mathrm{m}$ [20]. Also, it has been reported that in comparison with silicon solar cells (amorphous, polycrystalline and monocrystalline), the EPBT and the price of thin films have been lower, although the efficiency is not as high as silicon solar cells [21].
Nevertheless, in attempting to be a better contender in front of silicon photovoltaics, some materials have been performed. Copper indium gallium selenide (CIGS) is one of the best absorber materials in thin films, because it possesses a chalcopyrite crystal structure and can modify the band gap energy values changing indium by gallium and obtaining $\mathrm{CuInSe}_{2}$ and $\mathrm{CuGaSe}_{2}$ with 1.02 and $1.67 \mathrm{eV}$ [22]. Another material is cadmium telluride (CdTe) with a band gap energy of $1.5 \mathrm{eV}$ which gives it a theoretical efficiency of around 30\% (see section 4.4) and the most attractive characteristic of this material is its chemical simplicity so that it could be applied to space applications [21]. Also, gallium arsenide (GaAs) is used in thin films and by the year 2014, this material had been shown the best efficiency by a single junction (27.6\%) [23]. In addition, GaAs uses a band gap between 1.43 and $1.7 \mathrm{eV}$ [14]. 
The next generation of solar cells is covered by organic solar cells (OSCs) or organic photovoltaics (OPV). These cells are based on photosynthesis process in order to absorbing light which is done by the dye that substitutes the silicon, compared with conventional cells; however, they have been demonstrated with low efficiency of around 3-5\% [24] and they are still a promising alternative because of their low cost and relative ease of chemical synthesis [25]. Even though only some materials have been presented, there are a huge variety of solar cells materials. Figure 3 shows the three biggest blocks of these materials.

\section{Applied Review Methodology}

This methodology is based on a comprehensive method to evaluate and analyse, along the whole product lifetime, the environmental performance and energy consumption, covering the whole processes [27] having a life cycle assessment as principal analogy. Therefore, it has been proposed and standardised by ISO 14040 and ISO 14044 [28] [29] using some fundamental stages: first is goal and scope; second is life cycle inventory; third impacts assessment and fourth is the interpretation of the results [30]. Hence, taking the impact into consideration in this study, the following points were analysed: diverse aspects of GHG emissions, EPBT, ERoEI, the efficiency, how suitable it could be with respect to the potentiality of the territory and how much it could be, in order to demonstrate that this alternative can be a substitute of fossil fuels, being applied specifically to Brazil.

\section{Results and Discussion}

\section{Efficiency}

\section{Efficiency of Solar Cells}

The first essential point to be evaluated, which has been studied along the years, is the efficiency that most of the green parameters depend on the efficiency to be better, such as recovering the invested energy, trying to get shorter time and producing even more energy. Also, low equivalent $\mathrm{CO}_{2}$ emissions are expected by energy
Table 1: Efficiency by materials.

\begin{tabular}{|c|c|c|c|}
\hline Material & $\begin{array}{c}\text { Efficiency } \\
(\%)\end{array}$ & Reference & Year \\
\hline GaAs & 23.5 & [31] & 2011 \\
\hline CZTS & 7.3 & [32] & 2012 \\
\hline Poly-Si & 20.3 & [33] & 2012 \\
\hline CZTS & 8.9 & {$[34]$} & 2012 \\
\hline CIGS & 15.5 & [35] & 2012 \\
\hline DSC & 11.4 & {$[36]$} & 2012 \\
\hline OPV & 8.4 & [37] & 2012 \\
\hline InGa/GaAs & 26.6 & [38] & 2013 \\
\hline CZTS & 12.6 & [39] & 2013 \\
\hline DSC & 9.4 & [40] & 2013 \\
\hline $\mathrm{CdTe}$ & 12.3 & [41] & 2013 \\
\hline CIGS & 20.4 & [42] & 2013 \\
\hline CIGS & 15.2 & [43] & 2013 \\
\hline CZTS & 8.4 & [44] & 2013 \\
\hline $\begin{array}{l}\text { OPV-triple } \\
\text { junction }\end{array}$ & 11.55 & [45] & 2014 \\
\hline CZTS & 11.6 & [46] & 2014 \\
\hline Perovskite & 11.13 & [47] & 2014 \\
\hline Poly-Si & 18.45 & [48] & 2014 \\
\hline Mono-Si & 25.6 & [49] & 2014 \\
\hline Perovskite & 16.6 & {$[50]$} & 2014 \\
\hline Perovskite & 15.07 & [51] & 2014 \\
\hline OPV & 10.31 & [52] & 2014 \\
\hline Perovskite & 17.6 & [53] & 2015 \\
\hline Mono-Si & 20.6 & {$[54]$} & 2015 \\
\hline Mono-Si & 22.5 & [55] & 2015 \\
\hline Perovskite & 17.7 & [56] & 2015 \\
\hline Perovskite & 18.3 & [57] & 2015 \\
\hline CIGS & 21.7 & [58] & 2015 \\
\hline OPV & 9.94 & [59] & 2015 \\
\hline GaAs & 28 & [60] & 2015 \\
\hline $\mathrm{CdTe}$ & 21 & {$[60]$} & 2015 \\
\hline OPV & 11.25 & [61] & 2016 \\
\hline GaAs & 15.3 & [62] & 2016 \\
\hline Poly-Si & 21.25 & [63] & 2016 \\
\hline Mono-Si & 19.42 & [64] & 2016 \\
\hline Poly-Si & 16.7 & [64] & 2016 \\
\hline CdTe & 17 & [65] & 2016 \\
\hline Poly-Si & 18.62 & [66] & 2017 \\
\hline OPV & 13.1 & [67] & 2017 \\
\hline $\begin{array}{c}\text { Perovskite- } \\
\text { silicon }\end{array}$ & 26.4 & [68] & 2017 \\
\hline
\end{tabular}

produced along the lifetime, without affecting the efficiency. For this reason, the results from 39 different materials and studies are gathered and represented in Table 1. All these data are analysed by means of two graphs, first to com- 
Efficiency Divided by Materials

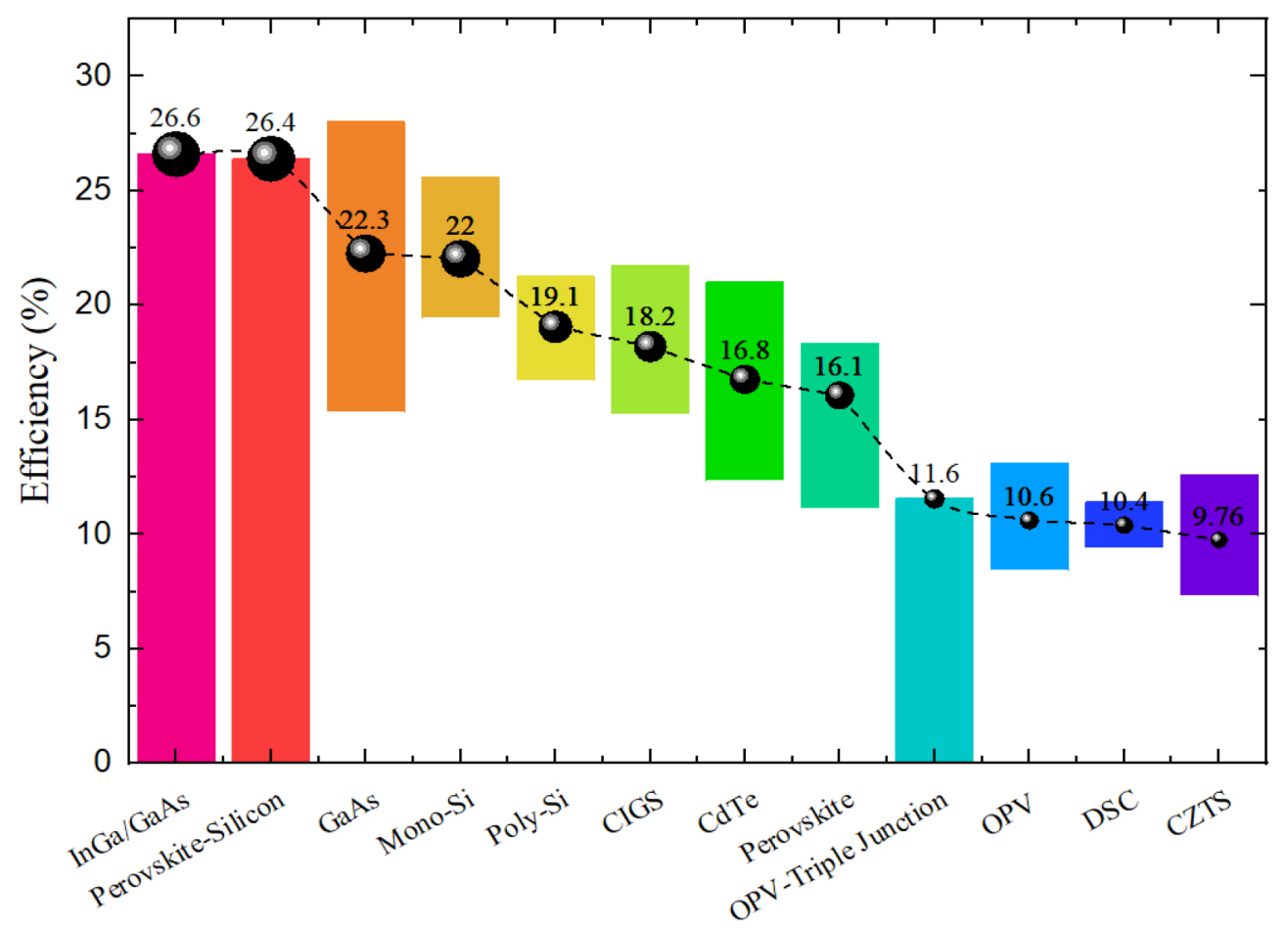

Figure 4: Efficiency divided by materials.

Efficiency Along the Years

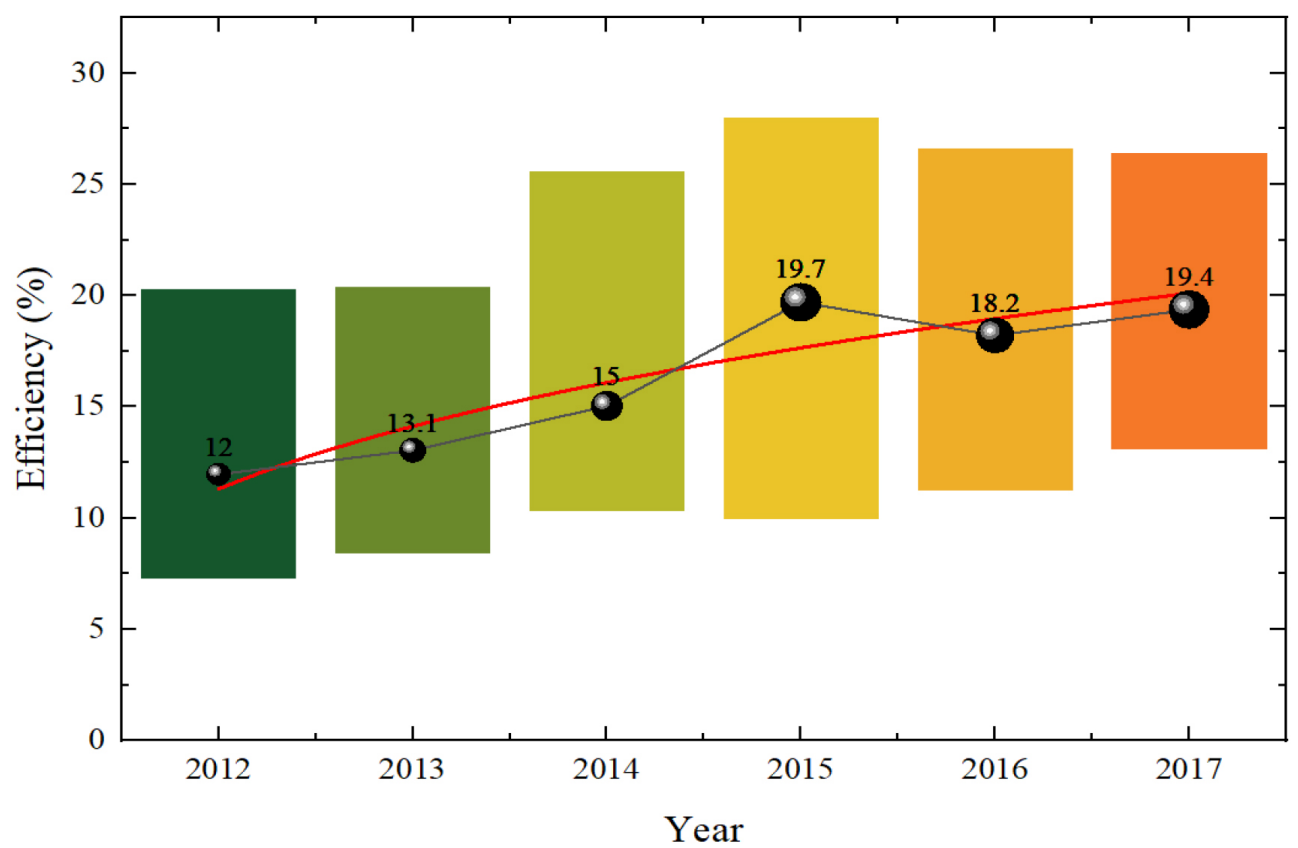

Figure 5: Efficiency along the time. 
pare the efficiencies by materials (Figure 4), and the other, along the last years, to average the different studies (Figure 5).

When the materials are seen, it is possible noticing a top around $26 \%$ of efficiency; also, the first three materials correspond to newer technologies like tandem (InGa/GaAs and perovskite/silicon) and thin films (GaAs). However, monocrystalline and polycrystalline silicons (which are the most commonly used) are ubicated later with the efficiencies of approximately $19 \%$ and $18 \%$. On the other hand, in recent years, the average efficiency of solar cells has been increasing.

Efficiency of solar cells in front of thermoelectrical plants

If the efficiency was compared with the thermoelectrical power plants, there would be still a gap between them, with a global average efficiency around 35\% [69] [70], which represents almost the double if compared with silicon solar cells (1.85 times). Also, if it is considered on account of the Brazilian case, there are some carbon power plants which have a varied efficiency, being $20.5 \%$ in Charqueadas power plant, $25 \%, 29,4 \%, 36.1 \%$ and $35.8 \%$ corresponding to Jorge Lacerda A1, A2, B and C, the most $36.5 \%$ belonging to Candiota III [71], but this corresponds only to $1.88 \%$ of the total produced energy in Brazil and $8.51 \%$ of thermoelectrical plants [72]. Besides, the biggest part is taken by thermoelectrical gas plant $(7.75 \%$ of total grid and $35.07 \%$ of thermoelectrical energy) which was reported a $42 \%$ of efficiency [71], obtaining a $5.14 \%$ of total energy grid by oil $(23.25 \%$ of thermoelectrical energy) with $34 \%$ of efficiency [73]. The rest is corresponded to biomass $(8.58 \%$ of total energy grid and $38.84 \%$ of thermoelectrical plants) having an efficiency around $23.05 \%$ in Brazil [72].

It could resemble that there is nothing to do against the efficiency of thermoelectrical power plants; however, observing the efficiency along the years, there has been a constant increase in efficiency which could then help developing better solar cells. Also, even when the carbon thermoelectrical efficiency is bigger than silicon solar cells, the $\mathrm{CO}_{2}$ emission is 20 times higher and when it is used as natural gas, the emissions are 10 times higher and 16 times higher for oil thermoelectrical plants [74] (this point will be analysed later). Hence, it is possible asking, is it fear, right or correct using thermoelectrical plants just because of increasing efficiency? It does not look like.

\section{Greenhouse Gases Emissions (Equivalent $\mathrm{CO}_{2}$ Emissions)}

$\mathrm{CO}_{2}$ emissions by energy produced in solar cells When evaluating the GHG emissions, the principal gas on which this parameter is based is $\mathrm{CO}_{2}$, assessing it along the whole life of the studied material and expressing its value in $\mathrm{CO}_{2} \mathrm{~g} / \mathrm{kWh}$. For that reason, in this section a total of 24 ref-

Table 2: $\mathrm{CO}_{2}$ emissions.

\begin{tabular}{ccccc} 
Material & CO $_{2}$ emission (g/KWh) & Reference & Year & Average $\mathbf{C O}_{\mathbf{2}}$ emission (g/kWh) \\
\hline Mono-Si & 131 & {$[75]$} & 2009 & 131.00 \\
\hline CdTe & 17 & {$[76]$} & 2010 & \multirow{2}{*}{36.00} \\
\hline CIGS & 33 & {$[76]$} & 2010 & \\
\hline CIGS & 44 & {$[77]$} & 2010 \\
\hline CdTe & 50 & {$[77]$} & 2010 & 47.21 \\
\hline OPV & 37.77 & {$[78]$} & 2011 & \\
\hline OPV & 56.65 & {$[78]$} & 2011 & \\
\hline Poly-Si & 88.74 & {$[79]$} & 2012 \\
\hline DSSC & 22.29 & {$[80]$} & 2012 \\
\hline CdTe & 48 & {$[80]$} & 2012 \\
\hline CIGS & 95 & {$[80]$} & 2012 \\
\hline Mono-Si & 61 & {$[81]$} & 2012 \\
\hline
\end{tabular}


Table 2: $\mathrm{CO}_{2}$ emissions (continue).

\begin{tabular}{|c|c|c|c|c|}
\hline Material & $\mathrm{CO}_{2}$ emission $(\mathrm{g} / \mathrm{KWh})$ & Reference & Year & Average $\mathrm{CO}_{2}$ emission $(\mathrm{g} / \mathrm{kWh})$ \\
\hline $\mathrm{CdTe}$ & 15.83 & [82] & 2013 & \multirow{10}{*}{ 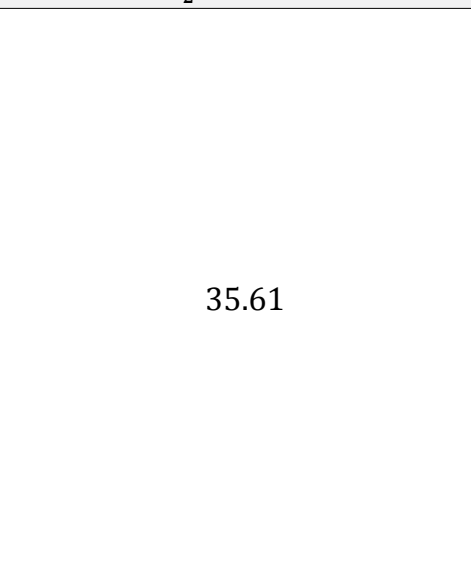 } \\
\hline $\mathrm{CdTe}$ & 20.11 & [82] & 2013 & \\
\hline CIGS & 21.44 & [82] & 2013 & \\
\hline Poly-Si & 27.2 & [82] & 2013 & \\
\hline CIGS & 27.64 & [82] & 2013 & \\
\hline Mono-Si & 38.06 & [82] & 2013 & \\
\hline Poly-Si & 49.7 & [82] & 2013 & \\
\hline Mono-Si & 81.2 & [82] & 2013 & \\
\hline Mono-Si & 47.9 & [83] & 2013 & \\
\hline $\begin{array}{c}\text { GaInP/ } \\
\text { GaInAs/Ge }\end{array}$ & 27 & [84] & 2013 & \\
\hline $\mathrm{CdTe}$ & 20 & [85] & 2014 & \multirow{19}{*}{36.73} \\
\hline CIGS & 22 & [85] & 2014 & \\
\hline OPV-Multi J. & 48.18 & [86] & 2014 & \\
\hline $\mathrm{CdTe}$ & 15.1 & [87] & 2014 & \\
\hline Poly-Si & 31.5 & [87] & 2014 & \\
\hline Mono-Si & 41.8 & [87] & 2014 & \\
\hline DSSC & 28.1 & [88] & 2014 & \\
\hline $\mathrm{CdTe}$ & 68 & [88] & 2014 & \\
\hline CIGS & 70 & [88] & 2014 & \\
\hline Poly-Si & 12.28 & [89] & 2014 & \\
\hline Poly-Si & 13.04 & [89] & 2014 & \\
\hline Poly-Si & 18.11 & [89] & 2014 & \\
\hline Poly-Si & 19.49 & [89] & 2014 & \\
\hline Poly-Si & 51.68 & [89] & 2014 & \\
\hline Poly-Si & 54.82 & [89] & 2014 & \\
\hline Poly-Si & 55.89 & [89] & 2014 & \\
\hline Poly-Si & 58.81 & [89] & 2014 & \\
\hline Poly-Si & 31.8 & [90] & 2014 & \\
\hline Mono-Si & 37.3 & [90] & 2014 & \\
\hline Poly-Si & 50.9 & [91] & 2015 & \multirow{3}{*}{64.50} \\
\hline Perovskite & 60.1 & [92] & 2015 & \\
\hline Perovskite & 82.5 & [92] & 2015 & \\
\hline Mono-Si & 5.6 & [93] & 2016 & \multirow{7}{*}{46.50} \\
\hline Mono-Si & 12.07 & [93] & 2016 & \\
\hline OPV & 14.7 & [94] & 2016 & \\
\hline Poly-Si & 60.1 & [95] & 2016 & \\
\hline Mono-Si & 65.2 & [95] & 2016 & \\
\hline Poly-Si & 80.5 & [95] & 2016 & \\
\hline Mono-Si & 87.3 & [95] & 2016 & \\
\hline
\end{tabular}


Table 2: $\mathrm{CO}_{2}$ emissions (continue).

\begin{tabular}{|c|c|c|c|c|}
\hline Material & $\mathrm{CO}_{2}$ emission $(\mathrm{g} / \mathrm{KWh})$ & Reference & Year & Average $\mathrm{CO}_{2}$ emission $(\mathrm{g} / \mathrm{kWh})$ \\
\hline CdTe & 35 & [14] & 2017 & \multirow{2}{*}{40.50} \\
\hline CIGS & 46 & {$[14]$} & 2017 & \\
\hline AZTS/Si & 19.8 & [96] & 2018 & \multirow{6}{*}{24.72} \\
\hline CZTS/Si & 20.4 & [96] & 2018 & \\
\hline CIGS/Si & 27.8 & [96] & 2018 & \\
\hline Poly-Si & 20.9 & [97] & 2018 & \\
\hline Poly-Si & 29.2 & [97] & 2018 & \\
\hline Poly-Si & 30.2 & [97] & 2018 & \\
\hline
\end{tabular}

\section{$\mathrm{CO}_{2}$ Emitted by Materials}

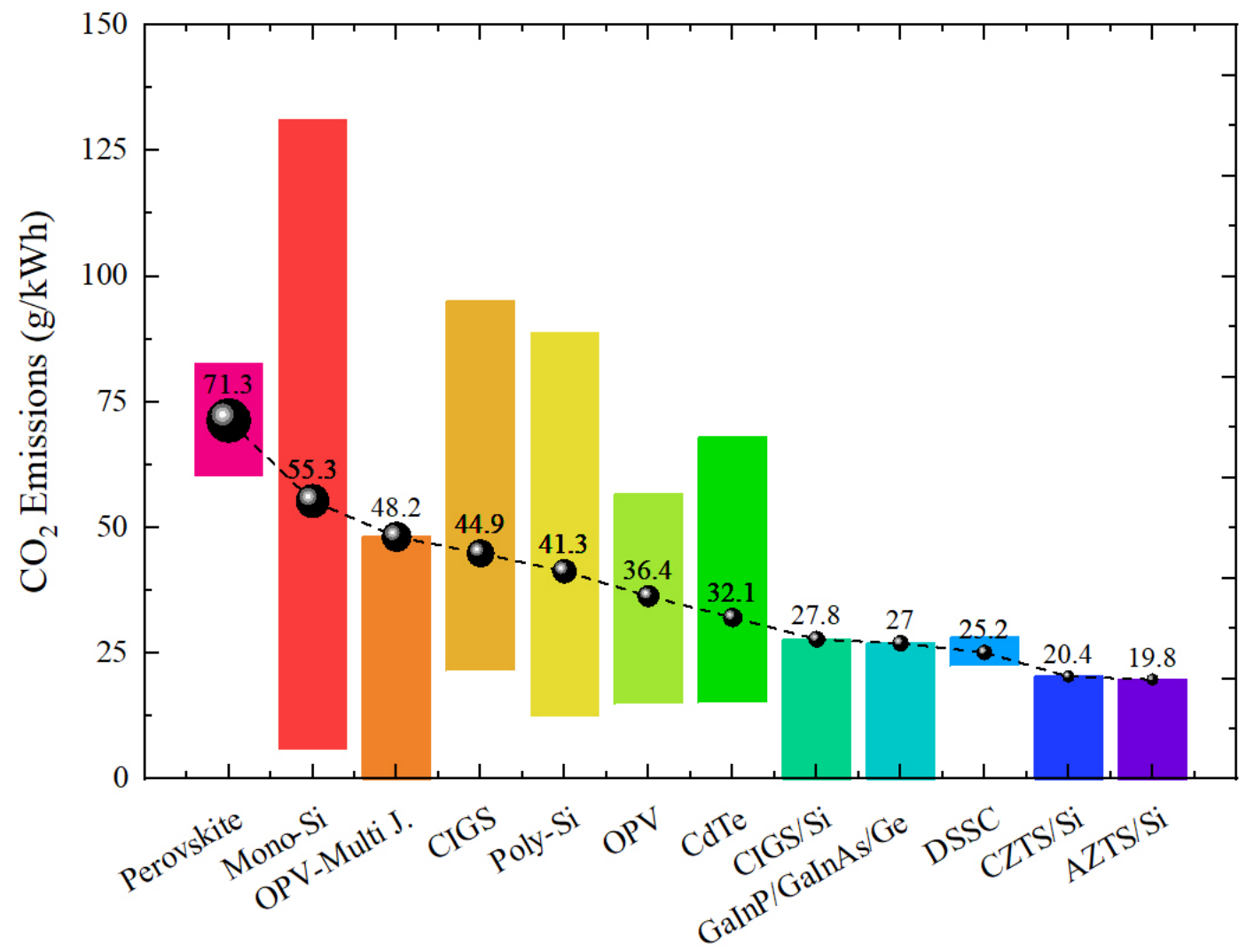

Figure 6: $\mathrm{CO}_{2}$ emission by different materials.

erences, from 2009 to 2019 (Table 2), was gathered, obtaining a graph (Figure 6) where the highest value is $131 \mathrm{CO}_{2} \mathrm{~g} / \mathrm{kWh}$, and the values correspond to the oldest data (2009). However, the average values by materials vary in a range of $\sim 20$ to $\sim 70 \mathrm{~g} / \mathrm{kWh}$ which shows an improved, although, relatively low value when compared with fossil fuel emissions. This will be discussed in the next subsection.

\section{$\mathrm{CO}_{2}$ emission compared with fossil fuels}

If all the data are averaged from Figure 6, it will be $42.15 \mathrm{CO}_{2} \mathrm{~g} / \mathrm{kWh}$. Also, using the data from International Energy Agency that pub- 
$\underline{\mathrm{CO}_{2}}$ Emission by Energy

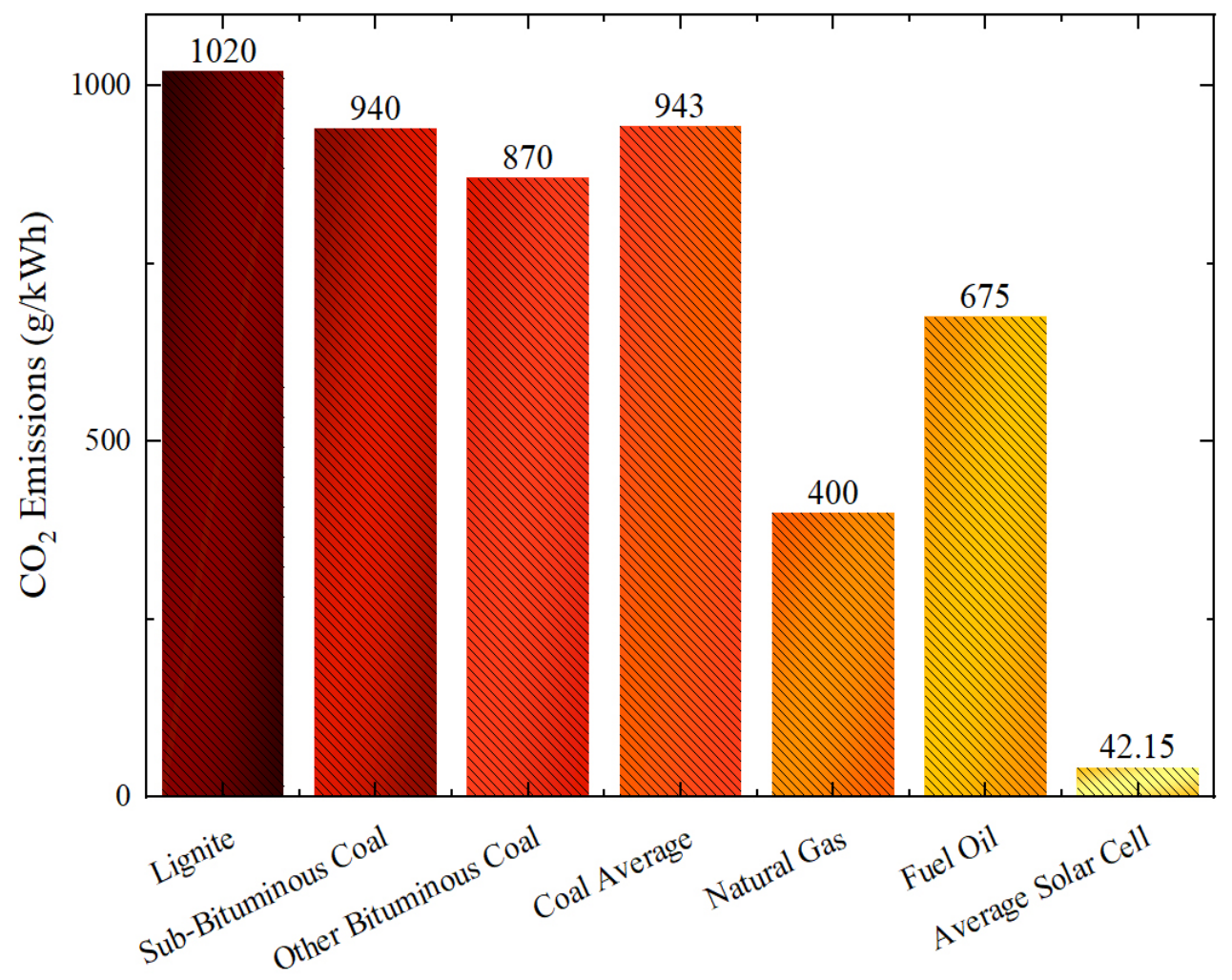

Figure 7: $\mathrm{CO}_{2}$ emission by energies.

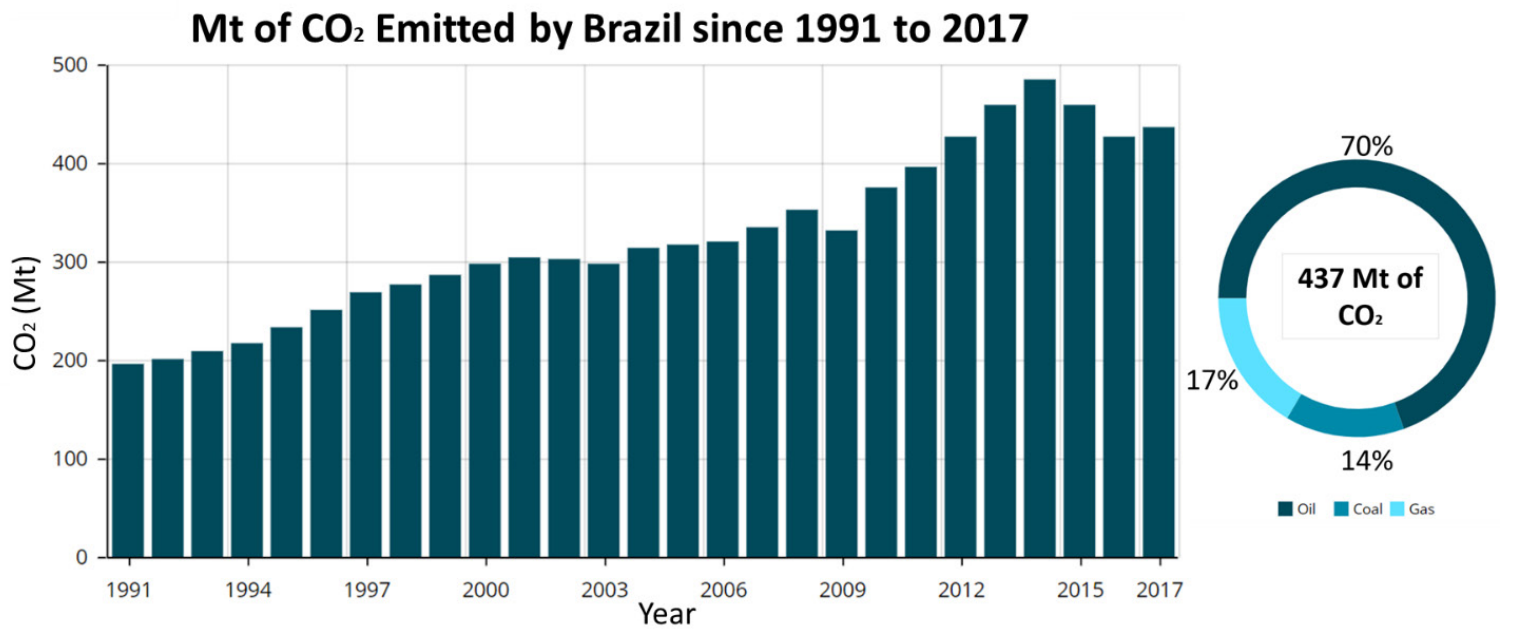

Figure 8: $\mathrm{CO}_{2}$ emitted by Brazil in 2017 [98].

lished its report about $\mathrm{CO}_{2}$ emissions from fuel combustion [74], a graph (Figure 7) is drawn to represent the big difference between them and a solar cell system; for this reason, the energy emitted by coal (average), natural gas and fuel oil contains approximately 22.37, 9.49 and 16.01 times more $\mathrm{CO}_{2}$ than an average photovoltaic panel. This leads to analyse the case of Brazil, which is shown in Figure 8, with a focus on the year 2017 (the last obtained data), and 


\section{$\mathrm{CO}_{2}$ Emission in Brazil Substituting for Solar Energy}

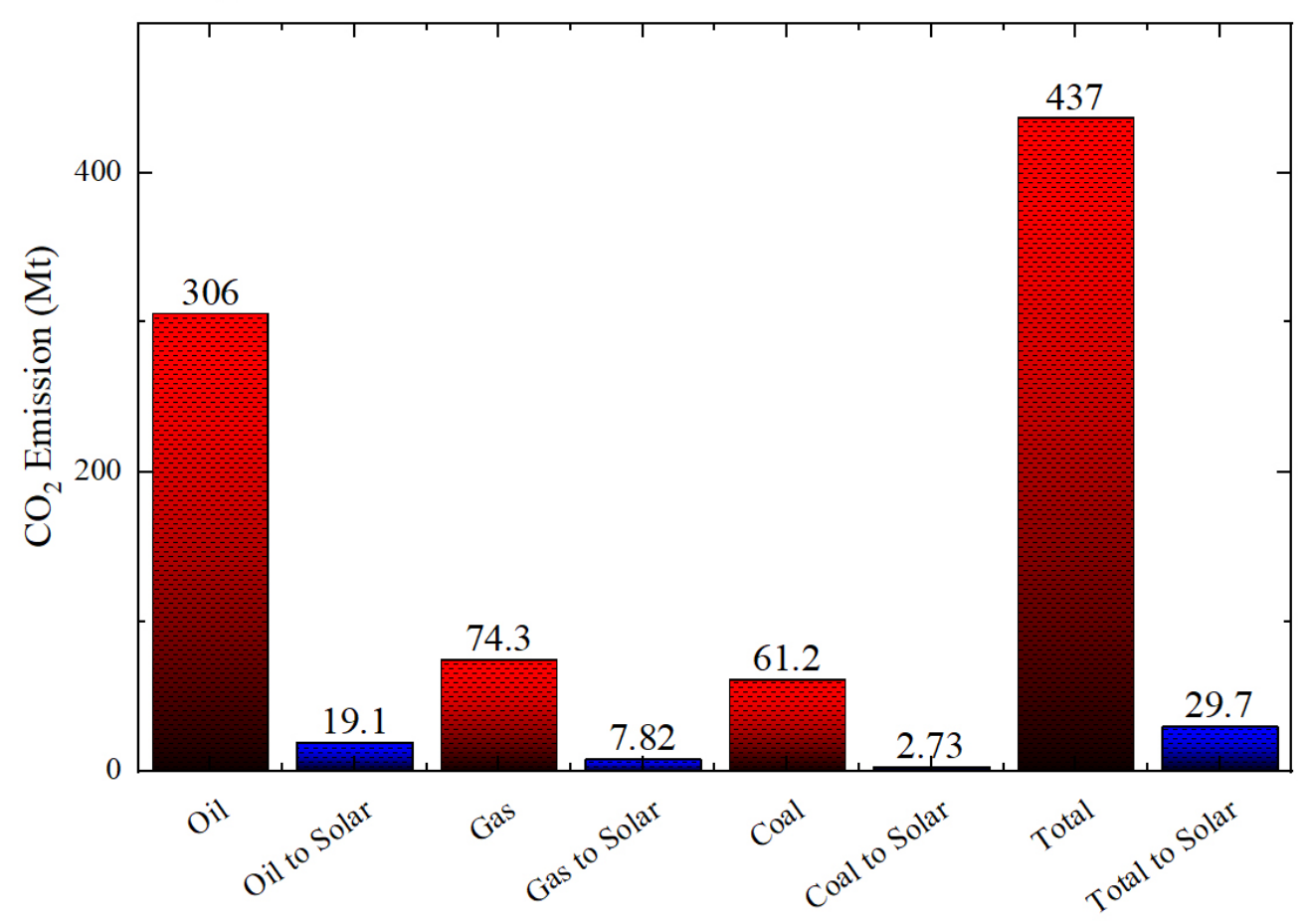

Figure 9: Emissions of $\mathrm{CO}_{2}$ if the fossil fuels are substituted by solar energy.

the data is divided by the emission by the fossil fuels the emissions of $\mathrm{CO}_{2}$ is calculated if they are substituted by solar panels (Figure 9), reducing from 437 to $29.7 \mathrm{Mt}$, being only $6.8 \%$ of the $\mathrm{CO}_{2}$ emitted nowadays.

\section{Energy Payback Time}

This parameter refers to the required time that the system takes to recover all the used energy from its cradle to grave [84]; for this reason, even when a system has low $\mathrm{CO}_{2}$ emission, it needs to recover its used energy as fast as possible, as a way to be sustainable. In this order of ideas, some studies have been gathered to analyse how these values have been developed (Table 3) by materials (Figure 10) and along the years (Figure 11).

Observing the graphs, it is notorious how the EPBT is decreasing with the years, varying with materials, getting even lower values than the average by year, nevertheless, there are no data in 2008, 2010 and also in 2009 but there was a data with a really high value. On the other hand, the evolution of EPBT could be defined in a range between 1 and 2.5 years, in average, to recover the used energy. However, it is valid asking if the obtained EPBT values are framing inside the lifetime of solar cells.

To answer the lifetime framework, an analytical review based on degradation rates of photovoltaics made by Jordan and Kurtz [106], the authors concluded that even when the companies warranty a lifetime of 25 years, moreover the reported report some panels with 40 years of duration. Also, they obtained degradation rates of $0.8 \%$ by year in average; in fact, $78 \%$ of their study reflected a degradation rate less than $1 \%$ by year, concluding that a range of 1 to 2.5 years to recover the energy is an excellent parameter. Additionally, in the Brazilian case, by the year of 2011, an EPBT was reported which varied between 3.1 and 4.1 years [107] (Figure 12), compared with the analysis in this review in the same year which was 3.9 years in average. Brazil fits good, besides, the tendency was from 3.9 years in 2011 to 1.26 years in 2018 for EPBT; for this reason, an interval could be proposed for Brazil (following the same tendency until 2018) from 1.085 to 1.435 years. 
Table 3: Energy payback time.

\begin{tabular}{|c|c|c|c|c|}
\hline Material & EPBT (year) & Reference & Year & EPBT average (year) \\
\hline GaAs & 5 & [99] & 2007 & \multirow{3}{*}{4.60} \\
\hline GaInP/GaAs & 4.6 & [99] & 2007 & \\
\hline Poly-Si & 4.2 & [99] & 2007 & \\
\hline Mono-Si & 9.08 & [75] & 2009 & 9.08 \\
\hline OPV & 2.02 & [78] & 2011 & \multirow{4}{*}{3.90} \\
\hline OPV & 1.35 & {$[78]$} & 2011 & \\
\hline Mono-Si & 8.04 & [100] & 2011 & \\
\hline Poly-Si & 4.18 & [100] & 2011 & \\
\hline Poly-Si & 4.17 & [79] & 2012 & \multirow{5}{*}{2.77} \\
\hline CIGS & 2.8 & [80] & 2012 & \\
\hline DSSC & 1.58 & [80] & 2012 & \\
\hline CdTe & 1.5 & [80] & 2012 & \\
\hline Mono-Si & 3.8 & [81] & 2012 & \\
\hline Mono-Si & 2.34 & [82] & 2013 & \multirow{10}{*}{1.68} \\
\hline Mono-Si & 1.96 & [82] & 2013 & \\
\hline Poly-Si & 1.45 & [82] & 2013 & \\
\hline Poly-Si & 1.24 & [82] & 2013 & \\
\hline CIGS & 1.02 & [82] & 2013 & \\
\hline CIGS & 1.01 & [82] & 2013 & \\
\hline CdTe & 0.68 & [82] & 2013 & \\
\hline $\mathrm{CdTe}$ & 0.68 & [82] & 2013 & \\
\hline Mono-Si & 5.5 & [83] & 2013 & \\
\hline GaInP/GaInAs/Ge & 0.9 & {$[84]$} & 2013 & \\
\hline OPV-Multi J. & 0.24 & [86] & 2014 & \multirow{9}{*}{1.74} \\
\hline Mono-Si & 3.11 & [87] & 2014 & \\
\hline Poly-Si & 2.97 & [87] & 2014 & \\
\hline $\mathrm{CdTe}$ & 0.94 & [87] & 2014 & \\
\hline CIGS & 1.98 & [88] & 2014 & \\
\hline CdTe & 1.95 & [88] & 2014 & \\
\hline DSSC & 0.95 & [88] & 2014 & \\
\hline Mono-Si & 1.9 & [90] & 2014 & \\
\hline Poly-Si & 1.6 & {$[90]$} & 2014 & \\
\hline Mono-Si & 4.1 & [101] & 2015 & \multirow{7}{*}{1.85} \\
\hline Poly-Si & 3.5 & [101] & 2015 & \\
\hline CIGS & 1.7 & [101] & 2015 & \\
\hline CdTe & 1 & [101] & 2015 & \\
\hline Poly-Si & 2.2 & [91] & 2015 & \\
\hline Perovskite & 0.266 & [92] & 2015 & \\
\hline Perovskite & 0.193 & [92] & 2015 & \\
\hline Mono-Si & 0.91 & [93] & 2016 & \multirow{6}{*}{1.34} \\
\hline Mono-Si & 0.42 & [93] & 2016 & \\
\hline OPV & 0.34 & [94] & 2016 & \\
\hline Poly-Si & 2.1 & [95] & 2016 & \\
\hline Mono-Si & 2.06 & [95] & 2016 & \\
\hline Mono-Si & 1.95 & [95] & 2016 & \\
\hline
\end{tabular}


Table 3: Energy payback time (continue).

\begin{tabular}{ccccc} 
Material & EPBT (year) & Reference & Year & EPBT average (year) \\
\hline Poly-Si & 1.6 & {$[95]$} & 2016 & 1.34 \\
\hline Perovskite-Si & 1.1 & {$[102]$} & 2017 \\
\hline Perovskite-CIGS & 0.625 & {$[102]$} & 2017 \\
\hline Perovskite-CZTS & 0.21 & {$[102]$} & 2017 \\
\hline Perovskite-perovskite & 0.11 & {$[102]$} & 2017 \\
\hline GaAs & 1.67 & {$[14]$} & 2017 \\
\hline CIGS & 1 & {$[14]$} & 2017 \\
\hline CdTe & 0.75 & {$[14]$} & 2017 \\
\hline Perovskite & 0.5 & {$[14]$} & 2017 \\
\hline Poly-Si & 2.3 & {$[103]$} & 2017 & \\
\hline Perovskite-Si & 0.88 & {$[104]$} & 2018 \\
\hline Perovskite-CIGS & 0.5 & {$[104]$} & 2018 \\
\hline Perovskite-CZTS & 0.45 & {$[104]$} & 2018 \\
\hline CIGS/Si & 1.4 & {$[96]$} & 2018 \\
\hline CZTS/Si & 1.3 & {$[96]$} & 2018 \\
\hline AZTS/Si & 1.3 & {$[96]$} & 2018 \\
\hline Poly-Si & 1.11 & {$[97]$} & 2018 \\
\hline Poly-Si & 1.08 & {$[97]$} & 2018 \\
\hline Poly-Si & 1.01 & {$[97]$} & 2018 \\
\hline CdTe & 3.6 & {$[105]$} & 2018 \\
\end{tabular}

Energy Payback Time by Materials

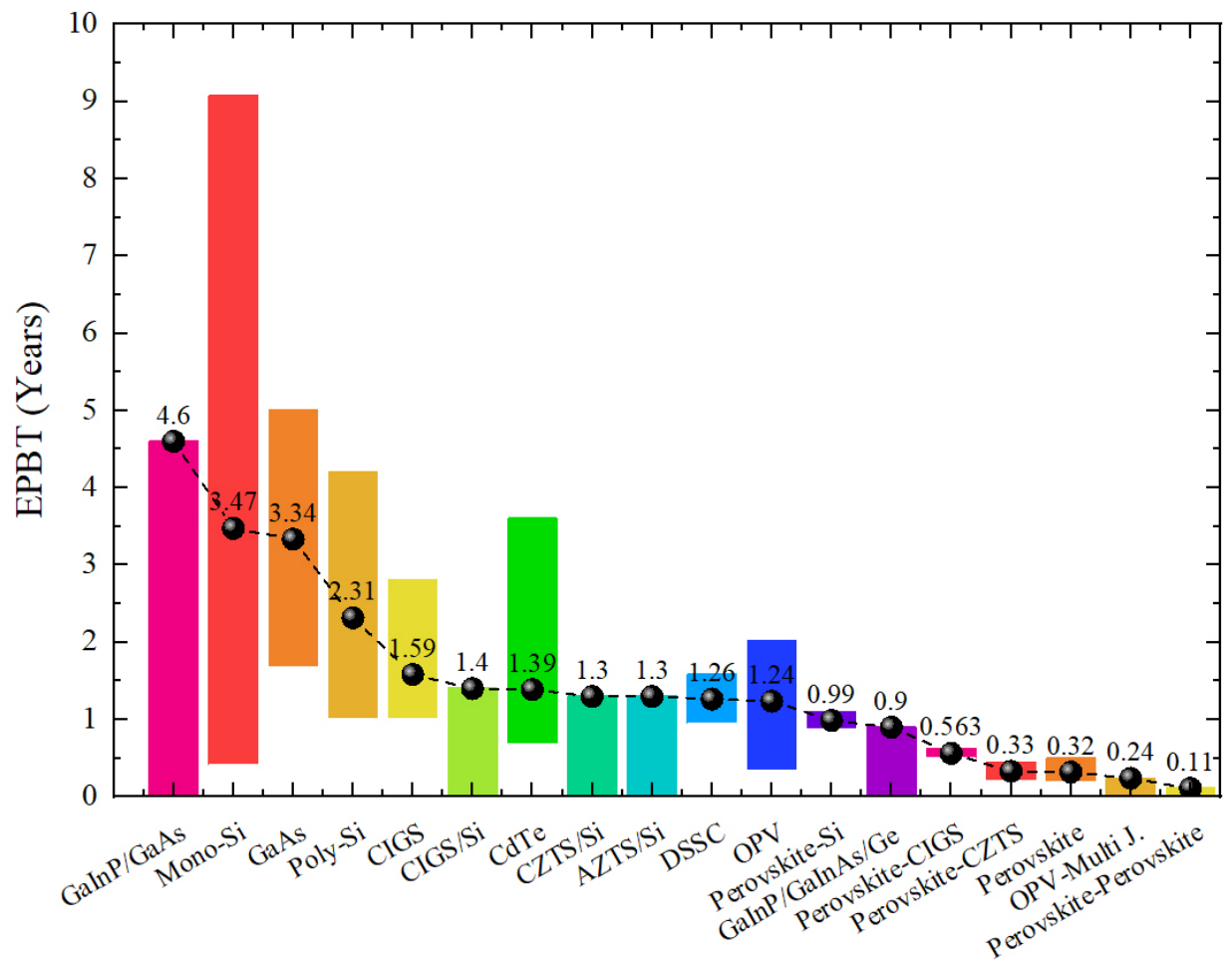

Figure 10: EPBT corresponding to each material. 


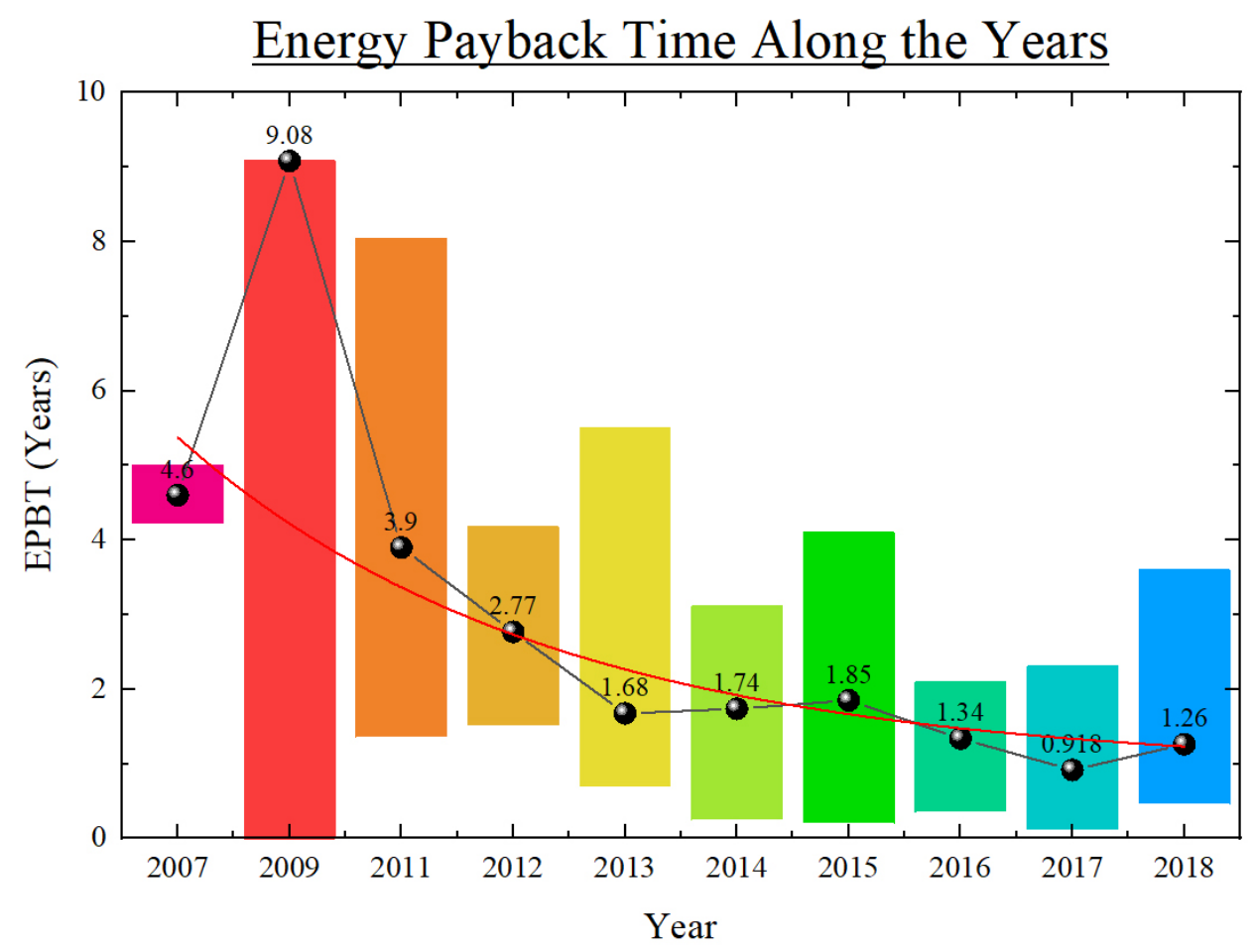

Figure 11: EPBT along the years with its corresponding average values and tendency.

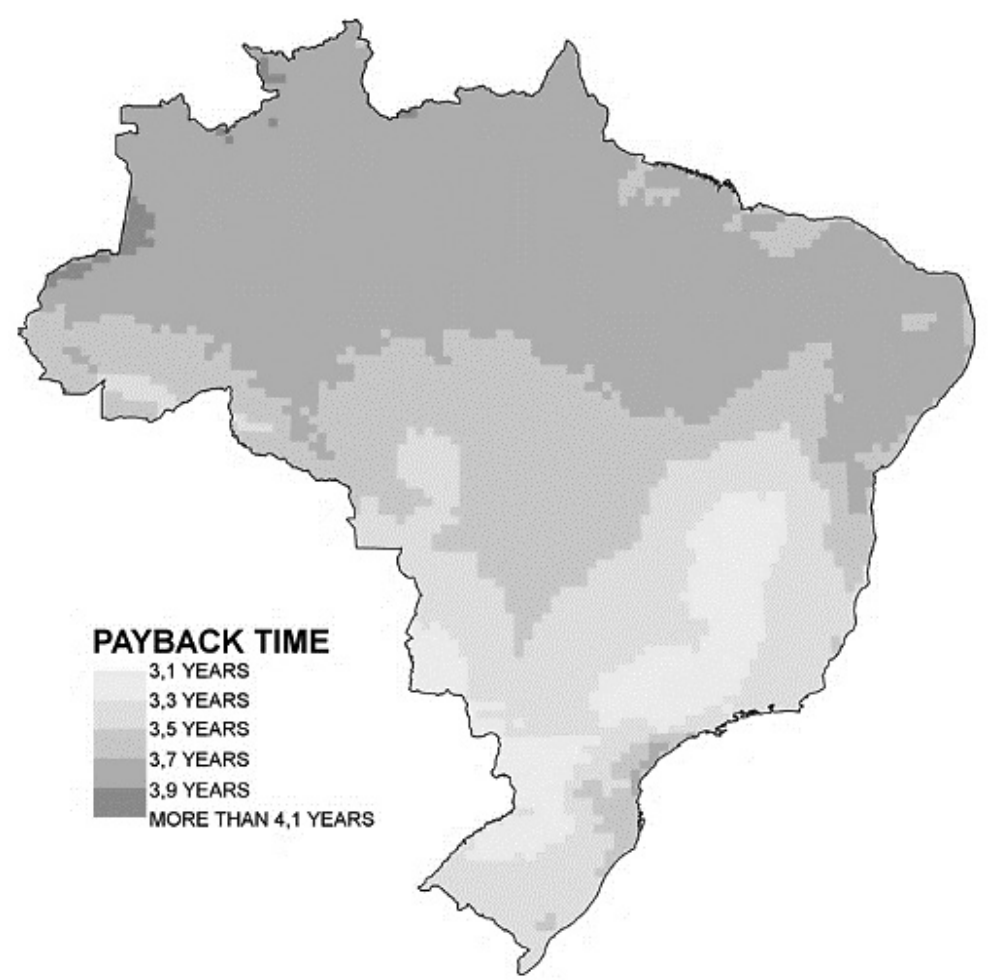

Figure 12: EPBT in Brazil using a low-cost solar system [107]. 


\section{Energy Return on Energy Invested}

ERoEI in solar cells

Another important parameter to be assessed is the ERoEI, which refers to the ratio between the energy generated and given to commercial usage and the input system energy along its lifetime, since cradle to its final dead use which can be recycled [108]. Having this data into consideration, the results from 19 different materials from 2012 to 2018 are considered (Table 4) and this parameter is graphed with respect to different materials (Figure 13), obtaining that the ERoEI varies from 5.2 to 16.9; however, as it is known that silicon panels are the most common, it can be taken in a range between 8.5 and 10.4 which are the average values for monocrystalline and polycrystalline silicon panels.

Table 4: ERoEl studies.

\begin{tabular}{|c|c|c|c|}
\hline Material & ERoEI & Reference & Year \\
\hline Poly-Si & 4.83 & [79] & 2012 \\
\hline CdTe & 13.33 & {$[80]$} & 2012 \\
\hline CIGS & 7.14 & {$[80]$} & 2012 \\
\hline DSSC & 12.67 & {$[80]$} & 2012 \\
\hline Mono-Si & 6 & [109] & 2012 \\
\hline Poly-Si & 6 & [109] & 2013 \\
\hline CdTe & 12 & [109] & 2014 \\
\hline Mono-Si & 16.1 & [90] & 2014 \\
\hline Poly-Si & 19.1 & [90] & 2014 \\
\hline CdTe & 34.2 & [101] & 2015 \\
\hline CIGS & 19.9 & {$[101]$} & 2015 \\
\hline Mono-Si & 8.7 & {$[101]$} & 2015 \\
\hline Poly-Si & 11.6 & [101] & 2015 \\
\hline CdTe & 8 & [110] & 2016 \\
\hline Mono-Si & 3.3 & {$[110]$} & 2017 \\
\hline Mono-Si & 8.45 & {$[111]$} & 2017 \\
\hline $\begin{array}{l}\text { Perovskite- } \\
\text { CIGS }\end{array}$ & 9.2 & [104] & 2018 \\
\hline $\begin{array}{l}\text { Perovskite- } \\
\text { CZTS }\end{array}$ & 8.1 & {$[104]$} & 2018 \\
\hline Perovskite-Si & 5.2 & [104] & 2018 \\
\hline
\end{tabular}

ERoEI of solar cells in front of Brazilian grid

The range of solar cells obtained earlier has to be compared with those values corresponding to other energies, especially non-renewable energies, and some studies are shown in Table 5 and graphed (Figure 14) together with solar cells data, which were divided into two, only silicon solar cells (Solar-Si) and the average between solar cell materials (Solar-System).

If the Brazilian energy grid was analysed, it could be possible to notice that only $22.10 \%$ of the total energy is produced by thermoelectrical source, which is the most common pollutant (Figure 15). Also, as shown in Figure 14, the ERoEI could be reduced from a range between 18.3 and 13.1 (thermoelectrical plants from fossil fuels) to 9.45 , which has to be re-

Table 5: Different energies and their ERoEI.

\begin{tabular}{cccc} 
Energy & ERoEI & Reference & Year \\
\hline Oil and gas & 5.02 & {$[113]$} & 2007 \\
\hline Oil and gas & 10.65 & {$[113]$} & 2007 \\
\hline Oil and gas & 16 & {$[114]$} & 2008 \\
\hline Oil and gas & 13 & {$[114]$} & 2008 \\
\hline Oil and gas & 20 & {$[114]$} & 2009 \\
\hline Gas & 20 & {$[114]$} & 2009 \\
\hline Coal & 12 & {$[108]$} & 2010 \\
\hline Coal & 16 & {$[108]$} & 2010 \\
\hline Oil & 5.9 & {$[108]$} & 2010 \\
\hline Oil & 5 & {$[108]$} & 2010 \\
\hline Gas & 4.8 & {$[108]$} & 2010 \\
\hline Gas & 8.2 & {$[108]$} & 2010 \\
\hline Oil and gas & 10 & {$[115]$} & 2010 \\
\hline Coal & 27 & {$[115]$} & 2010 \\
\hline Coal & 28 & {$[116]$} & 2012 \\
\hline Oil and gas & 17 & {$[116]$} & 2012 \\
\hline Hydroelectric & 84 & {$[116]$} & 2012 \\
\hline Coal & 30 & {$[117]$} & 2013 \\
\hline Gas & 28 & {$[117]$} & 2013 \\
\hline Hydroelectric & 35 & {$[117]$} & 2013 \\
\hline Coal & 12 & {$[108]$} & 2015 \\
\hline Gas & 11 & {$[110]$} & 2016 \\
\hline Coal & 3 & {$[110]$} & 2016 \\
\hline Oil & 1.7 & {$[110]$} & 2016 \\
\hline Hydroelectric & 58 & {$[110]$} & 2016 \\
\hline & & & \\
\hline
\end{tabular}




\section{Energy Return on Energy Invested for Each Material}

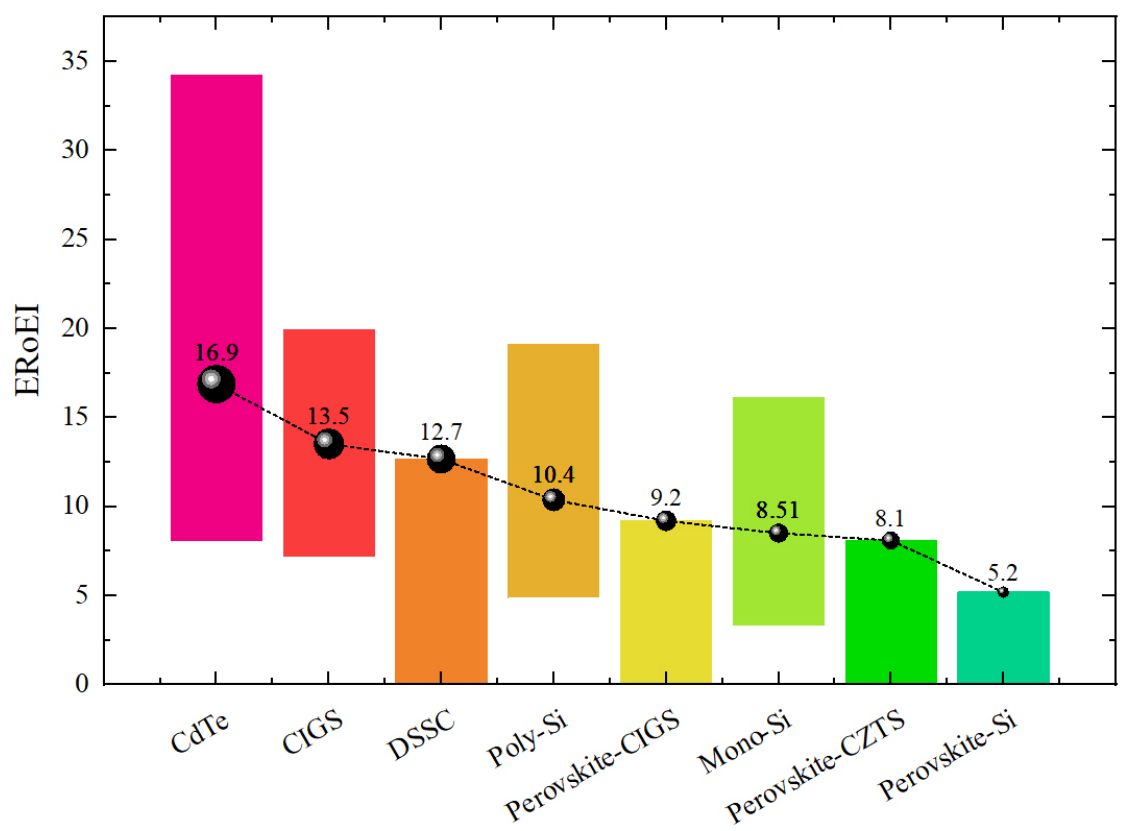

Figure 13: ERoEl corresponding to different materials and their average.

\section{Energy Return on Energy Invested According to Energies}

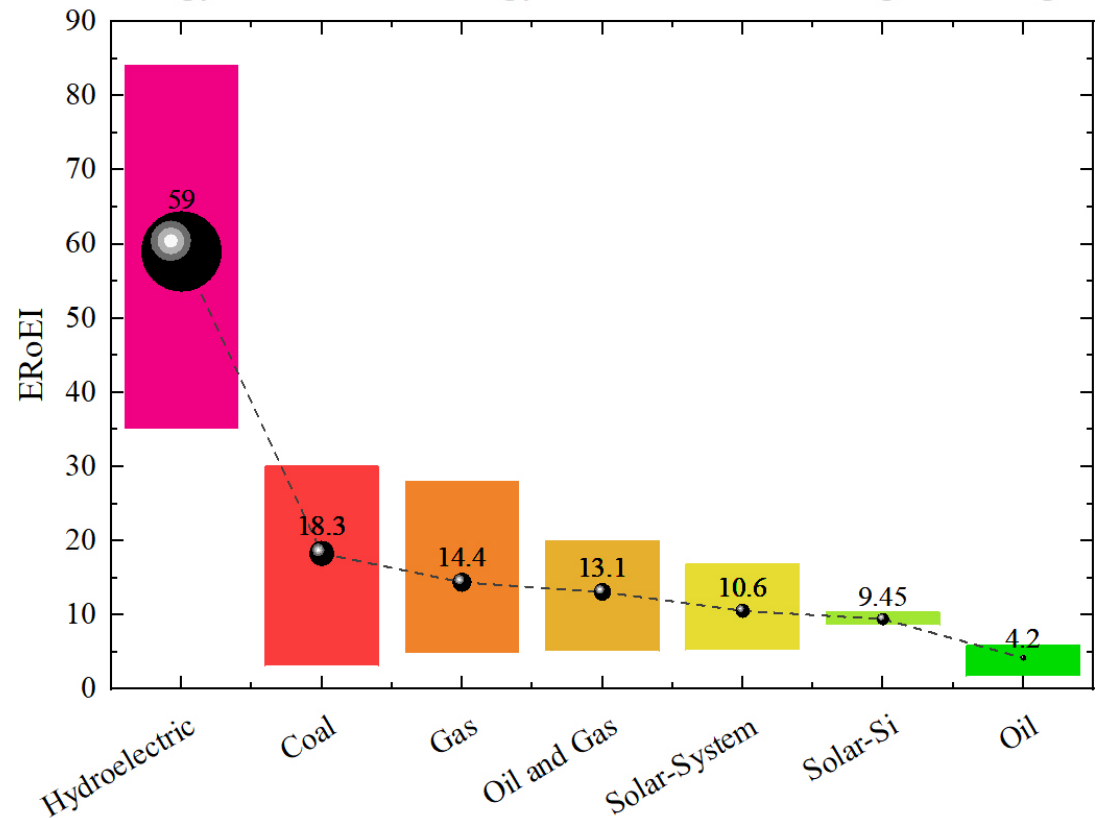

Figure 14: Different energies and their ERoEI.

duced further. However, analysing the total energy capacity in Brazil which is 156.4 GW [9], getting its maximum peak in the same month (70.66 GW) [112] and having thermoelectri- cal potential energy as $34.56 \mathrm{GW}$, then without this energy, the total capacity in Brazil would be $121.84 \mathrm{GW}$. Therefore, even when the ERoEI of solar cells is lower than the thermoelectrical 


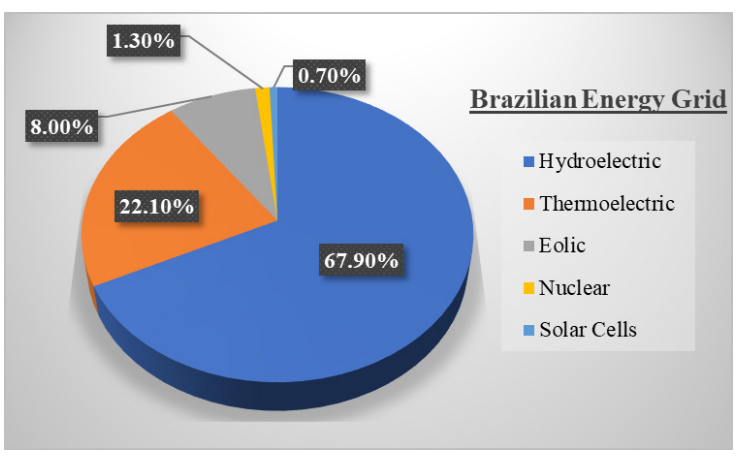

Figure 15: Brazilian energy grid (March 2018).

plants, the country would be stable if thermoelectrical plants were substituted by solar cells.

\section{The Brazilian Scenario}

\section{Potentiality of the territory}

The four important parameters to be evaluated in the performance of a green energy have been analysed; however, the economical aspect and application potentiality of the region have to be investigated. First, the irradiance is analysed (Figure 16) where Brazil is compared with Europe, obtaining similar, and even better, values, compared with other countries, such as Portugal, Spain and Germany, where the solar energy has been applied [118]. Also, the potential system that could exist in Brazil is $5153 \mathrm{Wh} / \mathrm{m}^{2}$ [119], and knowing they are of the country $\left(8.52 \times 1012 \mathrm{~m}^{2}\right)$ the potential energy is $43.96 \mathrm{PWh}(4.396 \times 1016 \mathrm{Wh})$. Compared with the maximum energy demand $(\approx 85,000 \mathrm{GW})$ [120], it is $0.085 \mathrm{PW}$ and $0.193 \%$ of the potentiality of solar cells energy; therefore, this result might be translated as $0.193 \%$ of the Brazilian territory could supply the energy demand.

\section{Economic aspect}

Another point is the economic aspect. It was analysed how could cost the energy by MWh, obtaining the levelised cost of energy (LCOE), in 2019, with the corresponding value of solar energy 45.7 US\$/MWh, compared with $39.1 \mathrm{US} \$ / \mathrm{MWh}$ in hydroelectrical industry, 104.3 US \$/MWh for thermoelectrical plant using coal and 46.3 US\$/MWh when the thermoelectrical plant is used for natural gas [121].

On the other hand, in 2015, the cost in Brazil for solar energy was studied, getting around 175 US $\$ / M W h$ [10], but using the tendency from 2015 to 2019 it could be reduced from around 0.6 to 0.244 US $\$ / \mathrm{Wp}$ [8], the value being $40.67 \%$ compared with the value 4 years ago. Therefore, it could be thought that in Brazil, nowadays, the projected value for solar
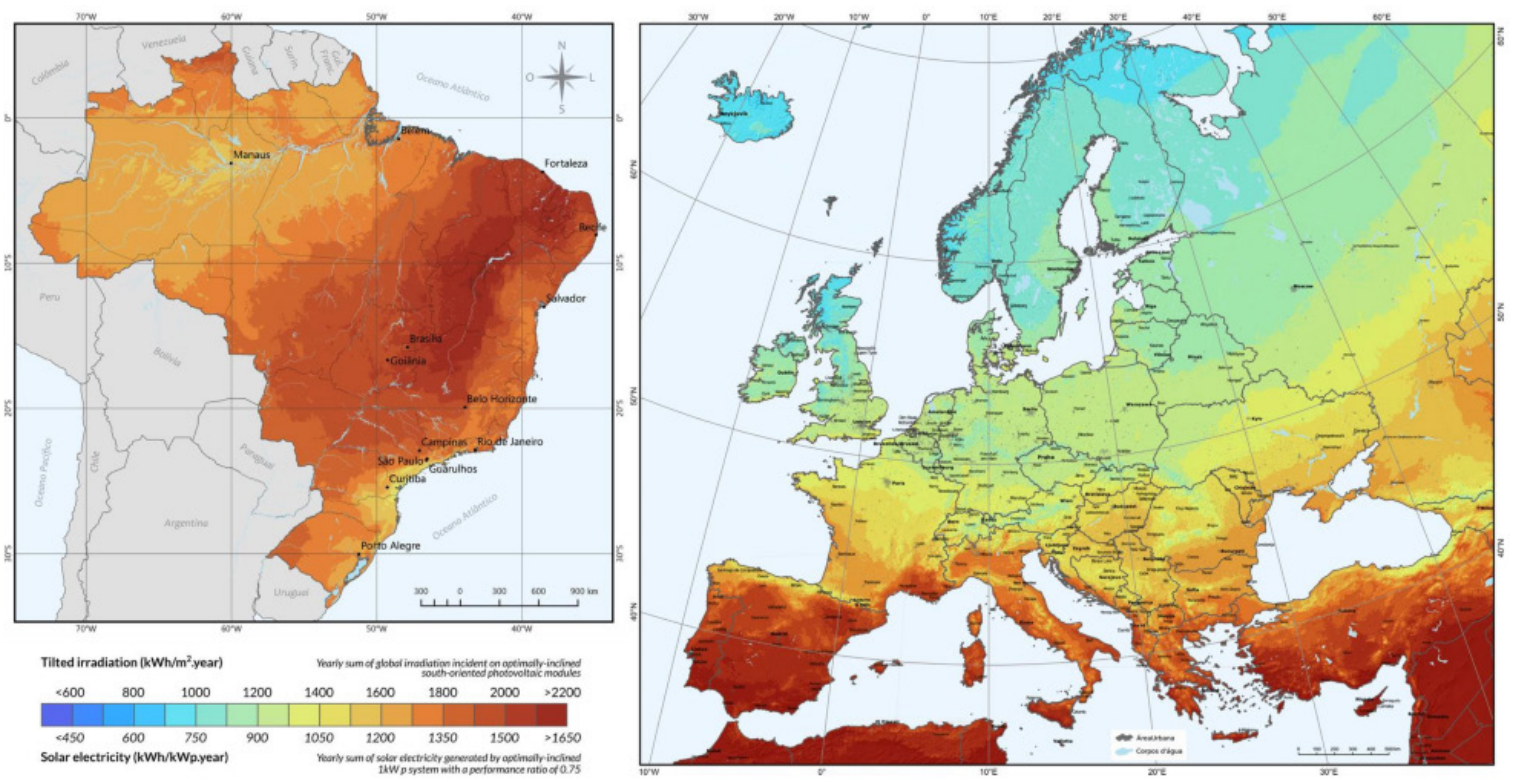
energy could cost $71.17 \mathrm{US} \$ / \mathrm{MWh}$ which is more competitive. Also, another studied value for Brazil is the price of carbon thermal plantwith a value between 70.9 and 100.6 US\$/MWh [71], being better using the solar energy.

\section{Conclusions}

In addition to all those mentioned and explained earlier, five critical points were analysed, observing the behaviour of solar cells and how they could act in the Brazilian scenario, and they are summarised below.

$\mathrm{CO}_{2}$ emissions: In this point, the emission generated by different solar panels along their lifetime was obtained, from the factory to the grave getting values from 19.8 to $71.3 \mathrm{CO}_{2} \mathrm{~g} / \mathrm{kWh}$ and being much lower than the energy from coal $\left(943 \mathrm{CO}_{2} \mathrm{~g} / \mathrm{kWh}\right)$. For this reason, if Brazil substitutes its fossil fuels to solar energy, the emissions could be reduced from 437 to $29.7 \mathrm{Mt}$ of $\mathrm{CO}_{2}$ by year, which is $6.8 \%$ of the actual emissions.

EPBT: Here, the time to recover all the used energy by solar panels varies from 0.11 to 4.6 years and in Brazil the value is around 3 to 4 years. There are improvements every year, having in consequence a reduction of this value. Also, they are good values that some companies offer a warranty of 25 years.

ERoEI: One of the most remarkable points was that photovoltaic panels can be compared with fossil fuels, showing better values than oil.

Efficiency: The efficiency has been a point with a constant increase every year, reaching $20 \%$ of efficiency easily, being rival to Brazilian thermoelectrical plants.

Cost and irradiance: Analysing the Brazilian case directly, the photovoltaic panels are more expensive than in Europe; nonetheless, they show a cheaper price than energy from coal. Also, the irradiance in Brazil is thus big that it is needed $0.2 \%$ of their territory to supply the national energy demand.

Finally, the solar energy presents low $\mathrm{CO}_{2}$ emissions, a fast payback time, good efficiency and lower prices every year showing how green it could be, and in the Brazilian case it is perfectly suitable because of all those points mentioned earlier, and the Brazilian territory presents a wonderful irradiance potential.

\section{Acknowledgements}

First, we acknowledge PUCRS because without the university this paper could have not happened. Also, we acknowledge CAPES, due to the scholarships received from them, which let us being at PUCRS.

\section{References}

[1] IPCC, "Climate Change 2014 Synthesis Report Summary for Policymakers," 2014.

[2] M. Zhang and S. Bachu, "Review of integrity of existing wells in relation to $\mathrm{CO}_{2}$ geological storage: What do we know?," International Journal of Greenhouse Gas Control, vol. 5, pp. 826-840, 2011.

[3] J.Y. Lee, M.S. Yu, K.H. Cha, S.Y. Lee, T.W. Lim and T. Hur, "A study on the environmental aspects of hydrogen pathways in Korea," International Journal of Hydrogen Energy, vol. 34, no. 20, pp. 8455-8467, 2009.

[4] H. Kim, K. Cha, V.M. Fthenakis, P. Sinha and T. Hur, "Life cycle assessment of cadmium telluride photovoltaic (CdTe PV) system," Solar Energy, vol. 103, pp. 74-88, 2014.

[5] Y. Wang, S. Zhou and H. Huo, "Cost and $\mathrm{CO}_{2}$ reductions of solar photovoltaic power generation in China: Perspectives for 2020," Renewable and Sustainable Energy Reviews, vol. 39, pp. 370-380, 2014.

[6] R. Kannan, K.C. Leong, H.K. Ho and C. Tso, "Life cycle assessment study of solar PV systems: An example of a $2.7 \mathrm{kWp}$ distributed solar PV system in Singapore," Solar Energy, vol. 8, no. 5, 2006.

[7] J. Peng, L. Lu and H. Yang, "Review on life cycle assessment of energy payback and greenhouse gas emission of solar photovoltaic systems," Renewable and Sustainable Energy Reviews, vol. 19, pp. 255-274, 2013.

[8] ITRPV, "International Technology Roadmap for Photovoltaic Results 2018," ITRPV, 2019.

[9] Operador Nacional do Sistema Elétrico, "ONS," March 2018. [Online]. Available: http://ons.org.br/ Paginas/resultados-da-operacao/historico-da-operacao/capacidade_instalada.aspx. [Accessed 7 April 2019].

[10] A. Ferreira, S.S. Kunh, K.C. Fagnani, T.A. De Souza, C. Tonezer, G. Dos Santos and C.H. Coimbra-Araújo, 
"Economic overview of the use and production of photovoltaic solar energy in brazil," Renewable and Sustainable Energy Reviews, vol. 81, 2018.

[11] P. d. Jong, T.B. Barreto, C.A. Tanajura, D. Kouloukoui, K.P. Oliveira-Esquerre, A. Kiperstok and E.A. Torres, "Estimating the impact of climate change on wind and solar energy in Brazil using a South American regional climate model," Renewable Energy, 2019.

[12] F. Martins, E. Pereira, S. Silva, S. Abreu and S. Colle, "Solar energy scenarios in Brazil, Part one: Resource assessment," Energy Policy, vol. 36, pp. 2853-2864, 2088.

[13] F. Martins, R. Rüther, E. Pereira and S. Abreu, "Solar energy scenarios in Brazil. Part two: Photovoltaics applications," Energy Policy, vol. 36, pp. 2865-2877, 2008.

[14] 0.0. Ogbomo, E.H. Amalu, N. Ekere and P. Olagbegi, "A review of photovoltaic module technologies for increased performance in tropical climate," Renewable and Sustainable Energy Reviews, vol. 75, 2017.

[15] S.A. Kalogirou, "Photovoltaic Systems- Processes and Systems," in Solar Energy Engineering, Academic Press, 2009, pp. 469-519.

[16] R.H. Plante, "Solar Photovoltaic Systems," in Solar Energy, Photovoltaics, and Domestic Hot Water A Technical and Economic Guide for Project Planners, Builders, and Property Owners, 2014, pp. 75-92.

[17] A.E. Brooks, "Solar Energy: Photovoltaics," in Future Energy (Second Edition) - Improved, Sustainable and Clean Options for our Planet, T.M. Letcher, Ed., 2014, pp. 383-404.

[18] L. Dobrzański, A. Drygała, M. Giedroć and M. Macek, "Monocrystalline silicon solar cells applied in photovoltaic system," The Journal of Achievements in Materials and Manufacturing Engineering, vol. 53, no. 1, July 2012.

[19] "Tindo Solar," [Online]. Available: http://www.tindosolar.com.au/learn-more/poly-vs-mono-crystalline/. [Accessed 4 April 2019].

[20] W. Hoffma and T. Pellkofer, "Thin films in photovoltaics: Technologies and perspectives," Thin Solid Films, vol. 520, pp. 4094-4100, 2012.

[21] S. Sundaram, K. Shanks and H. Upadhyaya, "Thin Film Photovoltaics," in A Comprehensive Guide to Solar Energy Systems With Special Focus on Photovoltaic Systems, 2018, pp. 361-370.

[22] Y. Tang, "Copper Indium Gallium Selenide Thin Film Solar Cells," in Nanostructured Solar Cells, 2017.

[23] N. Ekins-Daukes, "III-V Solar Cells," in Solar Cell Materials: Developing Technologies, G. Conibeer and A. Willoughby, Eds., 2014.
[24] S. Bhatia, "Solar photovoltaic systems," in Advanced Renewable Energy Systems, 2014, pp. 144-157.

[25] C. Amador-Bedolla, R. Olivares-Amaya, J. Hachmann and A. Aspuru-Guzik, "Organic Photovoltaics," in Informatics for Materials Science and Engineering Data-driven Discovery for Accelerated Experimentation and Application, 2013, pp. 423-442.

[26] T. Ibn-Mohammed, S.C.L. Koh, I.M. Reaney, A. Acquaye, G. Schileo, K.B. Mustapha and R.M. Greenough, "Perovskite solar cells: An integrated hybrid lifecycle assessment and review in comparison with other photovoltaic technologies," Renewable and Sustainable Energy Reviews, vol. 80, 2017.

[27] N.A. Ludin, N.I. Mustafa, M.M. Hanafiah, M.A. Ibrahim, M.A.M. Teridi, S. Sepeai, A. Zaharim and K. Sopian, "Prospects of life cycle assessment of renewable energy from solar photovoltaic technologies: A review," Renewable and Sustainable Energy Reviews, vol. 96, pp. 11-28, 2018.

[28] ISO, "ISO 14044 - Environmental management - Life cycle assessment - Requirements and guidelines," 2006.

[29] ISO, "ISO 14040 - Environmental management Life cycle assessment - Principles and framework," 2006.

[30] S. Gerbinet, S. Belboom and A. Léonard, "Life Cycle Analysis (LCA) of photovoltaic panels: A review," Renewable and Sustainable Energy Reviews, vol. 38, pp. 747-753, 2014.

[31] L.S. Mattos, S.R. Scully, M. Syfu, E. Olson, L. Yang, C. Ling, B.M. Kayes and G. He, "New module efficiency record: $23.5 \%$ under 1-sun illumination using thinfilm single-junction GaAs solar cells," in 2012 38th IEEE Photovoltaic Specialists Conference, 2012.

[32] S. Ahmed, K.B. Reuter, O. Gunawan, L. Guo, L.T. Romankiw and H. Deligianni, "A High Efficiency Electrodeposited Cu2ZnSnS4 Solar Cell," Advanced Energy Materials, vol. 2, no. 2, pp. 253-259, 2012.

[33] Z. Wang, P. Han, H. Lu, H. Qian, L. Chen, Q. Meng, N. Tang, F. Gao, Y. Jiang, J. Wu, W. Wu, H. Zhu, J. Ji, Z. Shi, A. Sugianto, L. Mai, B. Hallam and S. Wenham, "Advanced PERC and PERL production cells with 20.3\% record efficiency for standard commercial p-type silicon wafers," Progress in Photovoltaics, vol. 20, no. 3, pp. 260-268, 2012.

[34] B. Shin, Y. Zhu, N.A. Bojarczuk, S.J. Chey and S. Guha, "Control of an interfacial MoSe2 layer in Cu2ZnSnSe4 thin film solar cells: $8.9 \%$ power conversion efficiency with a TiN diffusion barrier," Applied Physics Letters, vol. 101, no. 5, 2012. 
[35] F. Karg, "High Efficiency CIGS Solar Modules," Energy Procedia, vol. 15, pp. 275-282, 2012.

[36] L. Han, A. Islam, H. Chen, C. Malapaka, B. Chiranjeevi, S. Zhang, X. Yang and M. Yanagida, "High-efficiency dye-sensitized solar cell with a novel co-adsorbent," Energy \& Environmental Science, vol. 5, no. 3, 2012.

[37] T. Yang, M. Wang, C. Duan, X. Hu, L. Huang, J. Peng, F. Huang and X. Gong, "Inverted polymer solar cells with $8.4 \%$ efficiency by conjugated polyelectrolyte," Energy \& Environmental Science, vol. 5, no. 8, 2012.

[38] D. Shahrjerdi, S.W. Bedell, C. Bayram, C.C. Lubguban, K. Fogel, P. Lauro, J.A. Ott, M. Hopstaken, M. Gayness and D. Sadana, "Ultralight High-Efficiency Flexible InGaP/(In)GaAs Tandem Solar Cells on Plastic," Advanced Energy Materials, vol. 3, no. 5, pp. 566-571, 2013.

[39] W. Wang, M.T. Winkler, O. Gunawan, T. Gokmen, T.K. Todorov, Y. Zhu and D.B. Mitzi, "Device Characteristics of CZTSSe Thin-Film Solar Cells with $12.6 \%$ Efficiency," Advanced Energy Materials, vol. 4, no. 7, 2014.

[40] H.-S. Kim, J.-W. Lee, N. Yantara, P.P. Boix, S.A. Kulkarni, S. Mhaisalkar, M. Grätzel and N.-G. Park, "High Efficiency Solid-State Sensitized Solar Cell-Based on Submicrometer Rutile TiO2 Nanorod and CH3NH3PbI3 Perovskite Sensitizer," Nano Letters, vol. 13, no. 6, p. 2412-2417, 2013.

[41] M.G. Panthani, J.M. Kurley, R.W. Crisp, T.C. Dietz, T. Ezzyat, J.M. Luther and D.V. Talapin, "High Efficiency Solution Processed Sintered CdTe Nanocrystal Solar Cells: The Role of Interfaces," Nano Letter, vol. 14, no. 2, p. 670-675, 2014.

[42] A. Chirilă, P. Reinhard, F. Pianezzi, P. Bloesch, A.R. Uhl, C. Fella, L. Kranz, D. Keller, C. Gretener, H. Hagendorfer, D. Jaeger, S.N. Rolf Erni, S. Buecheler and A.N. Tiwari, "Potassium-induced surface modification of $\mathrm{Cu}(\mathrm{In}, \mathrm{Ga}) \mathrm{Se} 2$ thin films for high-efficiency solar cells," Nature Materials, vol. 12, pp. 1107-111, 2013.

[43] T.K. Todorov, O. Gunawan, T. Gokmen and D.B. Mitzi, "Solution-processed $\mathrm{Cu}(\mathrm{In}, \mathrm{Ga})(\mathrm{S}, \mathrm{Se}) 2$ absorber yielding a 15.2\% efficient solar cell," Progress in Photovoltaics, vol. 21, no. 1, pp. 83-87, 2013.

[44] B. Shin, O. Gunawan, Y. Zhu, N.A. Bojarczuk, S.J. Chey and S. Guha, "Thin film solar cell with $8.4 \%$ power conversion efficiency using an earth-abundant Cu2ZnSnS4 absorber," Progress in Photovoltaics, vol. 21, no. 1, pp. 72-76, 2012

[45] C. Chen, W. Chang, K. Yoshimura, K. Ohya, J. You, J. Gao, Z. Hong and Y. Yang, "An Efficient Triple-Junction Polymer Solar Cell Having a Power Conversion
Efficiency Exceeding 11\%," Advanced Materials, vol. 26, no. 32, pp. 5670-5677, 2012.

[46] Y.S. Lee, T. Gershon, O. Gunawan, T.K. Todorov, T. Gokmen, Y. Virgus and S. Guha, "Cu2ZnSnSe4 ThinFilm Solar Cells by Thermal Co-evaporation with 11.6\% Efficiency and Improved Minority Carrier Diffusion Length," Advanced Energy Materials, vol. 5, no. 7, 2015.

[47] D.-Y. Son, J.-H. Im, H.-S. Kim and N.-G. Park, "11\% Efficient Perovskite Solar Cell Based on ZnO Nanorods: An Effective Charge Collection System," The Journal of Physical Chemistry, vol. 118, no. 30, p. 16567-16573, 2014.

[48] X. Ye, S. Zou, K. Chen, J. Li, J. Huang, F. Cao, X. Wang, L. Zhang, X. Wang, M. Shen and X. Su, "18.45\%-Efficient Multi-Crystalline Silicon Solar Cells with Novel Nanoscale Pseudo-Pyramid Texture," Advanced Functional Materials, vol. 24, no. 42, 2014.

[49] K. Masuko, M. Shigematsu, T. Hashiguchi, D. Fujishima, M. Kai, N. Yoshimura, T. Yamaguchi, Y. Ichihashi, T. Mishima, N. Matsubara, T. Yamanishi, T. Takahama, M. Taguchi, E. Maruyama and Shing, "Achievement of More Than 25\% Conversion Efficiency With Crystalline Silicon Heterojunction Solar Cell," Shingo Okamoto, vol. 4, no. 6, p. IEEE Journal of Photovoltaics, 2014.

[50] H. Zhou, Q. Chen, G. Li, S. Luo, T.-b. Song, H.-S. Duan, Z. Hong, J. You, Y. Liu and Y. Yang, "Interface engineering of highly efficient perovskite solar cells," Science, vol. 345, no. 6196, 2014.

[51] W. Ke, G. Fang, J. Wang, P. Qin, H. Tao, H. Lei, Q. Liu, X. Dai and a. X. Zhao, "Perovskite Solar Cell with an Efficient TiO2 Compact Film," Applied Materials Interfaces, vol. 6, no. 18, 2014.

[52] S.-H. Liao, H.-J. Jhuo, P.-N. Yeh, Y.-S. Cheng, Y.-L. Li, Y.H. Lee, S. Sharma and S.-A. Chen, "Single Junction Inverted Polymer Solar Cell Reaching Power Conversion Efficiency $10.31 \%$ by Employing Dual-Doped Zinc Oxide Nano-Film as Cathode Interlayer," $\mathrm{Na}$ ture, 2014

[53] C. Tao, S. Neutzner, L. Colella, S. Marras, A.R.S. Kandada, M. Gandini, M.D. Bastiani, G. Pace, L. Manna, M. Caironi, C. Bertarelliac and A. Petrozza, "17.6\% stabilized efficiency in low-temperature processed planar perovskite solar cells," Energy \& Environmental Science, vol. 8, pp. 2365-2370, 2015.

[54] S. Zhang, X. Pan, H. Jiao, W. Deng, J. Xu, Y. Chen, P.P. Altermatt, A. i. o. Z. Feng and P.J. Verlinden, in 2015 IEEE 42nd Photovoltaic Specialist Conference (PVSC), New Orleans, 2015. 
[55] E. Kobayashi, Y. Watabe, R. Hao and T.S. Ravi, "High efficiency heterojunction solar cells on n-type kerfless mono crystalline silicon wafers by epitaxial growth," Applied Physics Letter, vol. 106, 2015.

[56] W. Nie, H. Tsai, R. Asadpour, J.-C. Blancon, A.J. Neukirch, G. Gupta, J.J. Crochet, M. Chhowalla, S. Tretiak, M.A. Alam, H.-L. Wang and A.D. Mohit, "High-efficiency solution-processed perovskite solar cells with millimeter-scale grains," Science, vol. 347, no. 6221, pp. 522-525, 2015.

[57] N. Ahn, D.-Y. Son, I.-H. Jang, S.M. Kang, M. Choi and N.-G. Park, "Highly Reproducible Perovskite Solar Cells with Average Efficiency of $18.3 \%$ and Best Efficiency of $19.7 \%$ Fabricated via Lewis Base Adduct of Lead(II) Iodide," Journal of The American Chemical Society, vol. 137, no. 27, p. 8696-8699, 2015.

[58] T.M. Friedlmeier, P. Jackson, A. Bauer, D. Hariskos, O. Kiowski, R. Wuerz and M. Powalla, "Improved photocurrent in $\mathrm{Cu}(\mathrm{In}, \mathrm{Ga}) \mathrm{Se} 2$ solar cells: From 20.8\% to $21.7 \%$ efficiency," in 2015 IEEE 42nd Photovoltaic Specialist Conference (PVSC), New Orleans, 2015.

[59] Z. He, B. Xiao, F. Liu, H. Wu, Y. Yang, S. Xiao, C. Wang, T.P. Russell and Y. Cao, "Single-junction polymer solar cells with high efficiency and photovoltage," $\mathrm{Na}$ ture Photonics, vol. 9, p. 174-179, 2015.

[60] R.M. Geisthardt, M. Topič and J.R. Sites, "Status and Potential of CdTe Solar-Cell Efficiency," IEEE Journal of Photovoltaics, vol. 5, no. 4, pp. 1217 - 1221, 2015.

[61] W. Zhao, D. Qian, S. Zhang, S. Li, O. Inganäs, F. Gao and J. Hou, "Fullerene-Free Polymer Solar Cells with over 11\% Efficiency and Excellent Thermal Stability," Advanced Materials, vol. 28, p. 4734-4739, 2016.

[62] I. Åberg, G. Vescovi, D. Asoli, U. Naseem and J.P. Gilboy, "A GaAs Nanowire Array Solar Cell With 15.3\% Efficiency at 1 Sun," IEEE Journal of Photovoltaics, vol. 6, no. 1, pp. 185-190, 2016.

[63] W. Deng, F. Ye, Z. Xiong, D. Chen, W. Guo, Y. Chen, Y. Chen, P.P. Altermatt, Z. Feng and P.J. Verlinden, "Development of High-efficiency Industrial p-type Multi-crystalline PERC Solar Cells with Efficiency Greater Than 21\%," Energy Procedia, vol. 92, pp. 721-729, 2016.

[64] A. Tihane, M. Boulaid, L. Boughamrane, M. Nya, K. Bouabid and A. Ihlal, "Modeling and seasonal performance analysis of two monocrystalline and polycrystalline silicon photovoltaic modules," Materials Today: Proceedings, vol. 3, no. 7, pp. 2562-2569, 2016.

[65] Y. Zhao, M. Boccard, S. Liu, J. Becker, X.-H. Zhao, C.M. Campbell, E. Suarez, M.B. Lassise, Z. Holman and Y.H. Zhang, "Monocrystalline CdTe solar cells with open-circuit voltage over $1 \mathrm{~V}$ and efficiency of $17 \%$," Nature Energy, vol. 1, 2016.

[66] Y. Jiang, H. Shen, T. Pu, C. Zheng, Q. Tang, K. Gao, J. Wu, C. Rui, Y. Li and Y. Liu, "High efficiency multi-crystalline silicon solar cell with inverted pyramid nanostructure," Solar Energy, vol. 142, no. 15, pp. 91-96, 2017.

[67] W. Zhao, S. Li, H. Yao, S. Zhang, Y. Zhang, B. Yang and J. Hou, "Molecular Optimization Enables over $13 \%$ Efficiency in Organic Solar Cells," Journal of the American Chemical Society, vol. 139, no. 21, pp. 7148-7151, 2017.

[68] T. Duong, Y. Wu, H. Shen, J. Peng, X. Fu, D. Jacobs, E. Wang, T.C. Kho, K.C. Fong, M. Stocks, E. Franklin, A. Blakers, N. Zin, K. McIntosh, W.Li,Y. Cheng, T.P. White, K. Weber and K. Catchpole, "Rubidium Multication Perovskite with Optimized Bandgap for PerovskiteSilicon Tandem with over 26\% Efficiency," Advanced Energy Materials, vol. 7, no. 14, 2017.

[69] J. Wachsmuth, B. Dransfeld, H. Fekete, V. Duscha, M. Hagemann, N. Höhne, M. Reuter and F. Röben, "How Energy Efficiency Cuts Costs for a 2-Degree-Future," Fraunhofer Institute for Systems and Innovation Research ISI, 2015.

[70] G.C. Institute, "Efficiency in Thermal Power Generation," [Online]. Available: https://hub. globalccsinstitute.com/publications/energy-efficiency-technologies-overview-report/5-efficiency-thermal-power-generation. [Accessed 11 April 2019].

[71] E. d. P. E. (EPE), “Energia Termelétrica: Gás Natural, Biomassa, Carvão, Nuclear," Empresa de Pesquisa Energética (EPE), Rio de Janeiro, 2015.

[72] ANEEL, "Brazilian Energy Grid," 2018. [Online]. Available: http://www2.aneel.gov.br/aplicacoes/ capacidadebrasil/OperacaoCapacidadeBrasil.cfm. [Accessed 26 April 2019].

[73] IEMA, “Uso de água em termoelétricas," 2016.

[74] I. E. Agency, " $\mathrm{CO}_{2}$ emissions from fuel combustion," 2017.

[75] R. García-Valverde, C. Miguel, R. Martínez-Béjar and A. Urbina, "Life cycle assessment study of a $4.2 \mathrm{kWp}$ stand-alone photovoltaic system," Solar Energy, vol. 83, no. 9, pp. 1434-1445, 2009.

[76] A. Dominguez-Ramos, M. Held, R. Aldaco, M. Fischer and A. Irabien, "Prospective $\mathrm{CO}_{2}$ emissions from energy supplying systems: photovoltaic systems and conventional grid within Spanish frame conditions," The International Journal of Life Cycle Assessment, vol. 15, no. 6, pp. 554-566, 2010. 
[77] M. Ito, K. Komoto and K. Kurokawa, "Life-cycle analyses of very-large scale PV systems using six types of PV modules," Current Applied Physics, vol. 10, no. 2, 2010.

[78] N. Espinosa, R. García-Valverde, A. Urbina and F.C. Krebs, "A life cycle analysis of polymer solar cell modules prepared using roll-to-roll methods under ambient conditions," Solar Energy Materials and Solar Cells, vol. 95, no. 5, pp. 1293-1302, 2011.

[79] U. Desideri, S. Proietti, F. Zepparelli, P. Sdringola and S. Bini, "Life Cycle Assessment of a ground-mounted $1778 \mathrm{kWp}$ photovoltaic plant and comparison with traditional energy production systems," Applied Energy, vol. 97, pp. 930-943, 2012.

[80] M.L. Parisi, A. Sinicropi and R. Basosi, "Life cycle assessment of thin film non conventional photovoltaics: the case of dye sensitized solar cells," in The 25th International Conference on Efficiency, Cost, Optimization, Simulation and Environmental Impact of Energy Systems, 2012.

[81] M.J.R. Perez, V. Fthenakis, H. Kim and A.O. Pereira, "Façade-integrated photovoltaics: a life cycle and performance assessment case study," Progress in Photovoltaics, vol. 20, no. 8, pp. 975-990, 2012.

[82] M.J.D. Wild-Scholten, "Energy payback time and carbon footprint of commercial photovoltaic systems," Solar Energy Materials and Solar Cells, vol. 119, pp. 296-305, 2013.

[83] U. Desideri, F. Zepparelli, V. Morettini and E. Garroni, "Comparative analysis of concentrating solar power and photovoltaic technologies: Technical and environmental evaluations," Applied Energy, vol. 102, pp. 765-784, 2013.

[84] V.M. Fthenakis and H.C. Kim, "Life cycle assessment of high-concentration photovoltaic systems," Progress in Photovoltaics, vol. 21, no. 3, pp. 379-388, 2013.

[85] J.D. Bergesen, G.A. Heath, T. Gibon and S. Suh, "ThinFilm Photovoltaic Power Generation Offers Decreasing Greenhouse Gas Emissions and Increasing Environmental Co-benefits in the Long Term," Environmental Science \& Technology, vol. 48, no. 16, pp. 9834-9843, 2014.

[86] N. Espinosa and F.C. Krebs, "Life cycle analysis of organic tandem solar cells: When are they warranted?," Solar Energy Materials and Solar Cells, vol. 120, pp. 692-700, 2014.

[87] H. Kim, K. Cha, V.M. Fthenakis, P. Sinha and T. Hur, "Life cycle assessment of cadmium telluride photovoltaic (CdTe PV) systems," Solar Energy, vol. 103, pp. 78-88, 2014.
[88] M.L. Parisi, S. Maranghi and R. Basosi, "The evolution of the dye sensitized solar cells from Grätzel prototype to up-scaled solar applications: A life cycle assessment approach," Renewable and Sustainable Energy Reviews, vol. 39, pp. 124-138, 2014.

[89] N. Stylos and C. Koroneos, "Carbon footprint of polycrystalline photovoltaic systems," Journal of Cleaner Production, vol. 64, pp. 639-645, 2014.

[90] D. Yue, F. You and S.B. Darling, "Domestic and overseas manufacturing scenarios of silicon-based photovoltaics: Life cycle energy and environmental comparative analysis," Solar Energy, vol. 105, pp. 669-678, 2014.

[91] Y. Fu, X. Liu and Z. Yuan, "Life-cycle assessment of multi-crystalline photovoltaic (PV) systems in China," Journal of Cleaner Production, vol. 85, pp. 180-190, 2015.

[92] J. Gong, S.B. Darling and a. F. You, "Perovskite photovoltaics: life-cycle assessment of energy and environmental impacts," Energy \& Environmental Science, vol. 8, no. 7, pp. 1953-1968, 2015.

[93] W. Chen, J. Hong, X. Yuan and J. Liu, "Environmental impact assessment of monocrystalline silicon solar photovoltaic cell production: a case study in China," Journal of Cleaner Production, vol. 112, pp. 1025-1032, 2016.

[94] D. Hengevoss, C. Baumgartner, G. Nisato and C. Hugi, "Life Cycle Assessment and eco-efficiency of prospective, flexible, tandem organic photovoltaic module," Solar Energy, vol. 131, pp. 317-327, 2016.

[95] G. Hou, H. Sun, Z. Jiang, Z. Pan, Y. Wang, X. Zhang, Y. Zhao and $Q$. Yao, "Life cycle assessment of grid-connected photovoltaic power generation from crystalline silicon solar modules in China," Applied Energy, vol. 164, pp. 882-890, 2016.

[96] M.M. Lunardi, S. Moore, J.P. Alvarez-Gaitan, C. Yan, X. Hao and R. Corkish, "A comparative life cycle assessment of chalcogenide/Si tandem solar modules," Energy, vol. 145, pp. 700-709, 2018.

[97] W. Luo, Y.S. Khoo, A. Kumar, J.S.C. Low, Y.Li,Y.S. Tan, Y. Wang, A.G. Aberle and S. Ramakrishna, "A comparative life-cycle assessment of photovoltaic electricity generation in Singapore by multicrystalline silicon technologies," Solar Energy Materials and Solar Cells, vol. 174, pp. 157-162, 2018.

[98] Enerdata, “Global Energy Statistical Yearbook 2018," 2018. [Online]. Available: https://yearbook.enerdata.net/co2-fuel-combustion/CO2-emissions-data-from-fuel-combustion.html. [Accessed 7 April 2019]. 
[99] N.J. Mohr, J.J. Schermer, M.A.J. Huijbregts, A. Meijer and L. Reijnders, "Life cycle assessment of thin-film GaAs and GaInP/GaAs solar modules," Progress in Photovoltaics, vol. 15, no. 2, pp. 163-179, 2007.

[100] A. Sumper, M. Robledo-García, R. Villafáfila-Robles, J. Bergas-Jané and J. Andrés-Peiró, "Life-cycle assessment of a photovoltaic system in Catalonia (Spain)," Renewable and Sustainable Energy Reviews, vol. 15, no. 8, pp. 3888-3896, 2011.

[101] K.P. Bhandari, J.M. Collier, R.J. Ellingson and D.S. Apul, "Energy payback time (EPBT) and energy return on energy invested (EROI) of solar photovoltaic systems: A systematic review and meta-analysis," Renewable and Sustainable Energy Reviews, vol. 47, pp. 133-141, 2015.

[102] I. Celik, A.B. Phillips, Z. Song, Y. Yan, R.J. Ellingson, M.J. Heben and D. Apul, "Environmental analysis of perovskites and other relevant solar cell technologies in a tandem configuration," Energy \& Environmental Science, vol. 10, pp. 1874-1884, 2017.

[103] P. Wu, X. Ma, J. Ji and Y. Ma, "Review on Life Cycle Assessment of Energy Payback of Solar Photovoltaic Systems and a Case Study," Energy Procedia, vol. 105, pp. 68-74, 2017.

[104] I. Celik, A.B. Philips, Z. Song, Y. Yan, R.J. Ellingson, M.J. Heben and D. Apul, "Energy Payback Time (EPBT) and Energy Return on Energy Invested (EROI) of Perovskite Tandem Photovoltaic Solar Cells," IEEE Journal of Photovoltaics, vol. 8, no. 1, pp. 305 - 309, 2018.

[105] P. Rajput, Y.K. Singh, G. Tiwari, O. Sastry, S. Dubey and K. Pandey, "Life cycle assessment of the $3.2 \mathrm{~kW}$ cadmium telluride (CdTe) photovoltaic system in composite climate of India," Solar Energy, vol. 159, pp. 415-422, 2018.

[106] D.C. Jordan and S.R. Kurtz, "Photovoltaic Degradation Rates - An Analytical Review," National Renewable Energy Laboratory, 2012.

[107] F.R. Martins and E.B. Pereira, "Enhancing information for solar and wind energy technology deployment in Brazil," Energy Policy, vol. 39, no. 7, pp. 4378-4390, 2011.

[108] A. Arvesen and E.G. Hertwich, "More caution is needed when using life cycle assessment to determine energy return on investment (EROI)," Energy Policy, vol. 76, pp. 1-6, 2015.

[109] M. Raugei, P. Fullana-i-Palmer and V. Fthenakis, "The energy return on energy investment (EROI) of photovoltaics: Methodology and comparisons with fossil fuel life cycles," Energy Policy, vol. 45, pp. 576-582, 2012.
[110] M. Raugei and E. Leccisi, "A comprehensive assessment of the energy performance of the full range of electricity generation technologies deployed in the United Kingdom," Energy Policy, vol. 90, pp. 45-59, 2016.

[111] M. Raugei, S. Sgouridis, D. Murphy, V. Fthenakis, R. Frischknecht, C. Breyer, U. Bardi, C. Barnhart, A. Buckley, M. Carbajales-Dale, D. Csala, M. de Wild-Scholten, G. Heath, A. Jæger-Waldau, C. Jones, A. Keller, E. Leccisi, P. Mancarella, N. Pearsall, A. Siegel, W. Sinke and P. Stolz, "Energy Return on Energy Invested (ERoEI) for photovoltaic solar systems in regions of moderate insolation: A comprehensive response," Energy Policy, vol. 102, pp. 377-384, 2017.

[112] Operador Nacional do Sistema Elétrico, “ONS," March 2018. [Online]. Available: http://ons.org.br/ Paginas/resultados-da-operacao/historico-da-operacao/carga_energia.aspx. [Accessed 7 April 2019].

[113] M.C. Guilford, C.A. Hall, P. O'Connor and C.J. Cleveland, "A New Long Term Assessment of Energy Return on Investment (EROI) for U.S. Oil and Gas Discovery and Production," Sustainability, vol. 3, no. 10, pp. 1866-1887, 2011.

[114] J. Freise, "The EROI of Conventional Canadian Natural Gas Production," Sustainability, vol. 3, no. 11, pp. 2080-2104, 2011.

[115] Y. Hu, C.A. Hall, J. Wang, L. Feng and A. Poisson, "Energy Return on Investment (EROI) of China's conventional fossil fuels: Historical and future trends," Energy, vol. 54, pp. 352-364, 2013.

[116] J. Lambert, C. Hall, S. Balogh, A. Poisson and A. Gupta, "EROI of Global Energy Resources Preliminary Status and Trends," 2012.

[117] D. Weißbach, G. Ruprecht, A. Huke, K. Czerski, S. Gottlieb and A.H. Hussein, "Energy intensities, EROIs (energy returned on invested), and energy payback times of electricity generating power plants," Energy, vol. 52, pp. 210-221, 2013.

[118] E. Bueno, "Overview of Solar Energy in Brazil," Fundación de Apoyo a la Investigación del Estado de São Paulo, São Paulo, 2017.

[119] INPE, "Brazilian Atlas of Solar Energy," 2017.

[120] H.H. Zurn, D. Tenfen, J.G. Rolim, A. Richter and I. Hauer, "Electrical energy demand efficiency efforts in Brazil, past, lessons learned, present and future: A critical review," Renewable and Sustainable Energy Reviews, vol. 67, pp. 1081-1086, 2017.

[121] U.S. Energy Information Administration, "Levelized Cost and Levelized Avoided Cost of New Generation Resources in the Annual Energy Outlook 2019," 2019. 